\title{
When It Comes to an End: Oxidative Stress Crosstalk with Protein Aggregation and Neuroinflammation Induce Neurodegeneration
}

\author{
Patrycja Michalska ${ }^{1,2, *}$ and Rafael León ${ }^{1,2,3, * \mathbb{D}}$ \\ 1 Instituto Teófilo Hernando y Departamento de Farmacología y Terapéutica, Facultad de Medicina, \\ Universidad Autónoma de Madrid, 28029 Madrid, Spain \\ 2 Instituto de Investigación Sanitaria, Servicio de Farmacología Clínica, Hospital Universitario de la Princesa, \\ 28006 Madrid, Spain \\ 3 Instituto de Química Médica, Consejo Superior de Investigaciones Científicas (IQM-CSIC), \\ 28006 Madrid, Spain \\ * Correspondence: patrycja.michalska@uam.es (P.M.); rafael.leon@inv.uam.es (R.L.); \\ Tel.: +34-91-497-27-66 (P.M. \& R.L.)
}

Received: 29 June 2020; Accepted: 7 August 2020; Published: 12 August 2020

\begin{abstract}
Neurodegenerative diseases are characterized by a progressive loss of neurons in the brain or spinal cord that leads to a loss of function of the affected areas. The lack of effective treatments and the ever-increasing life expectancy is raising the number of individuals affected, having a tremendous social and economic impact. The brain is particularly vulnerable to oxidative damage given the high energy demand, low levels of antioxidant defenses, and high levels of metal ions. Driven by age-related changes, neurodegeneration is characterized by increased oxidative stress leading to irreversible neuronal damage, followed by cell death. Nevertheless, neurodegenerative diseases are known as complex pathologies where several mechanisms drive neuronal death. Herein we discuss the interplay among oxidative stress, proteinopathy, and neuroinflammation at the early stages of neurodegenerative diseases. Finally, we discuss the use of the Nrf2-ARE pathway as a potential therapeutic strategy based on these molecular mechanisms to develop transformative medicines.
\end{abstract}

Keywords: neurodegenerative diseases; oxidative stress; protein aggregates; neuroinflammation; Nrf2-ARE pathway; reactive species; redox signaling

\section{Introduction: Neurodegenerative Diseases}

Neurodegenerative diseases (NDDs) are a heterogeneous group of neurological disorders, characterized by a progressive loss of particular subsets of neurons in different functional anatomic systems of the brain or the spinal cord [1]. NDDs include Alzheimer's disease (AD), Parkinson's disease (PD), and Amyotrophic Lateral Sclerosis (ALS), among others.

Given the increase in life expectancy and the lack of effective treatments for NDDs, the already large number of affected individuals is expected to increase enormously. During the last decades, tremendous efforts have been made to find effective disease-modifying treatments for these devastating diseases; however, the lack of efficient diagnosis and the still unknown causes of NDDs have hampered the development of successful therapies. Current treatment options are mainly symptomatic, condemning these patients to progressive deterioration, and eventually, to death.

NDDs pathophysiology represents a complex network of pathological events where several factors participate in their onset and development. Increasing evidence demonstrates that NDDs share many common pathophysiological mechanisms [2-4]. Among them, oxidative stress (OS), mitochondrial 
dysfunction, metal ions accumulation, neuroinflammation, protein misfolding, cell-cell transmission of characteristic disease-related proteins and apoptotic neuronal death have been widely described.

Numerous genetic mutations are associated with the onset of NDDs [5]; however, these "familial forms" represent less than $5 \%$ of the cases, and therefore, the vast majority of the cases are sporadic. It is known that environmental factors, lifestyle, or vascular risk factors influence the apparition of NDDs [6], but still, the major known risk factor for most NDDs is aging. OS has been widely recognized as an important factor in the etiology of NDDs [7,8], yet its role as a cause or consequence is debated. Herein, we will define the role of OS and its connection with NDDs. Not only evidence of OS in NDDs will be highlighted; we will also address how this ubiquitous process triggers selective neuronal vulnerability. Importantly, the interplay between OS and major features of NDDs, cellular proteostasis, and neuroinflammation, as key drivers of neurodegeneration will be addressed. Finally, therapeutic strategies based on these common pathological mechanisms will be discussed.

\section{Reactive Species and Oxidative Stress}

Reactive species (RS) have gained attention in the biological context given their role in cellular signaling and disease [9]. They are generally categorized as Reactive Oxygen Species (ROS) and Reactive Nitrogen Species (RNS). The most relevant RS include: superoxide anion $\left(\mathrm{O}_{2}{ }^{\bullet-}\right)$; hydroxyl radical $\left({ }^{\bullet} \mathrm{OH}\right)$; nitric oxide $(\mathrm{NO})$; and non-radicals: hydrogen peroxide $\left(\mathrm{H}_{2} \mathrm{O}_{2}\right)$; peroxynitrite $\left(\mathrm{ONOO}^{-}\right)[10,11]$ (Figure 1).

In aerobic organisms, cellular metabolism is followed by oxygen-derived radical accumulation. RS play key physiological roles, being critical for cellular signaling and pro-survival pathways [12]; however, any disruption of the antioxidant/pro-oxidant balance in favor of the former leads to excessive RS generation called OS, causing toxic effects through irreversible damage to different biomolecules and alteration of different signaling pathways. While RS can be generated from several sources, numerous redox-sensitive targets and antioxidant systems control their cellular availability [13].

\subsection{Sources of Reactive Species}

Major sites of RS production are enzymatic endogenous sources, primarily the mitochondrial electron transport chain (ETC) [14] and the transmembrane NADPH oxidase (NOX) system [15], that form the superoxide anion $\left(\mathrm{O}_{2}{ }^{\bullet-}\right)$, which dismutates to form $\mathrm{H}_{2} \mathrm{O}_{2}$ and can be reduced to the hydroxyl radical $\left({ }^{\bullet} \mathrm{OH}\right)$ in metal-catalyzed Fenton reactions. $\mathrm{O}_{2}{ }^{\bullet-}$ can also react with other radicals, notably nitric oxide (NO), producing peroxynitrite $\left(\mathrm{ONOO}^{-}\right)$(Figure 1). Complex I and III of the ETC are responsible for superoxide production in the mitochondria via a non-enzymatic process, hence, at a higher rate of metabolism, $\mathrm{O}_{2}{ }^{\bullet-}$ production increases proportionally [16]. In fact, it is estimated that around $1-2 \%$ of the oxygen consumed reacts with electrons to form the superoxide anion [17]. Moreover, NOX occupy different cellular localizations and contribute to the local generation of $\mathrm{O}_{2}^{\bullet-}$.

There are other endogenous sources that contribute to RS production, e.g., peroxisomes [18]; the cytochrome P450 enzymes produce RS at the endoplasmic reticulum (ER) [19] or the mitochondrial enzyme monoamine oxidase (MAO) that catalyzes the oxidative deamination of biogenic amines, contribute to $\mathrm{H}_{2} \mathrm{O}_{2}$ production within the cells [20]. Cyclooxygenases (COX) and lipoxygenases (LOX) generate lipid-derived RS, such as prostaglandins [21] and leukotrienes [22], that are important mediators of inflammation. Lastly, exposure to environmental factors contributes to RS generation. Exogenous RS sources include drugs, heavy metals, pollutants, toxicants as well as UV and other ionizing radiation [23]. 


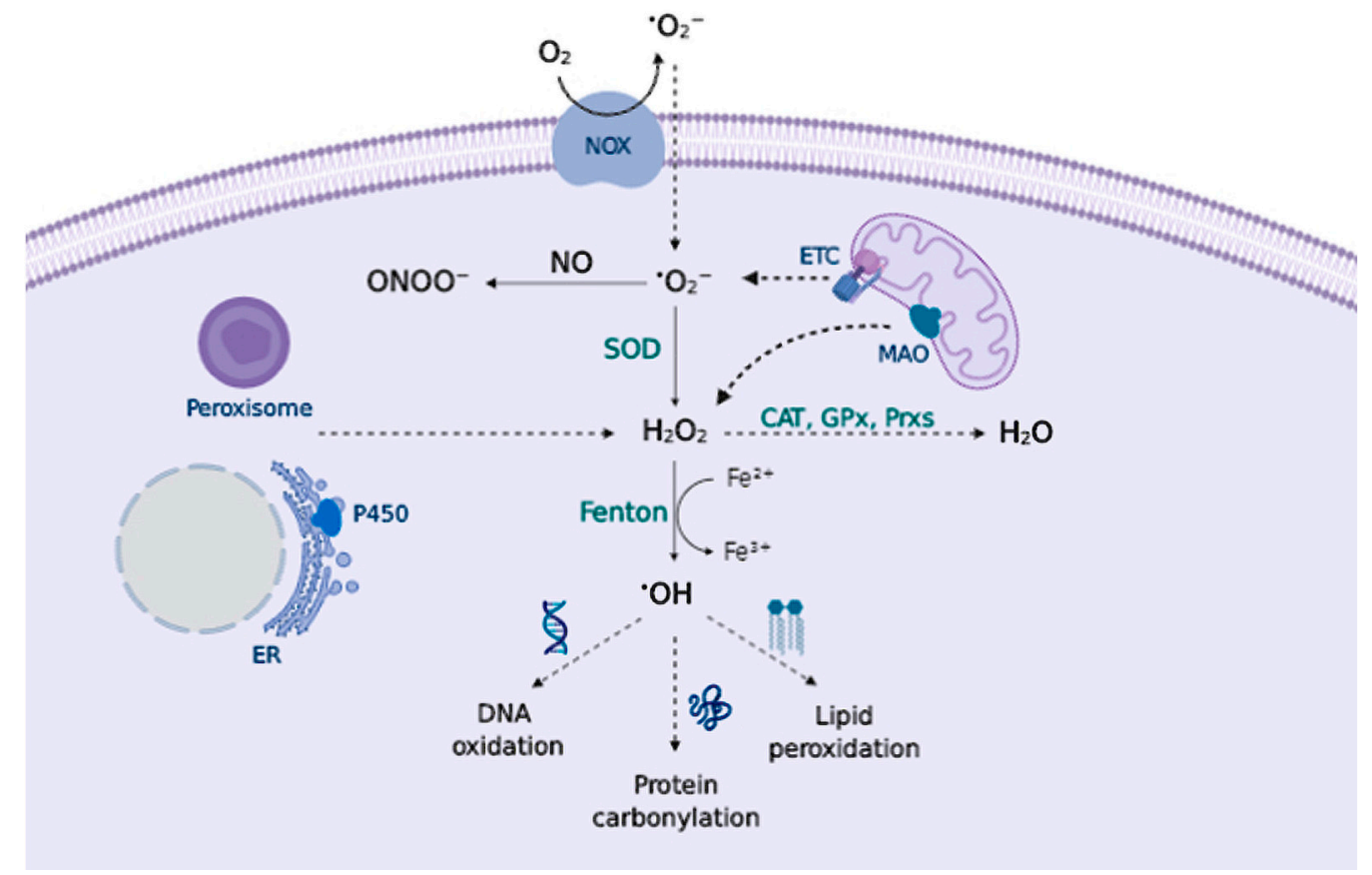

Figure 1. Principal RS sources and sinks. Transmembrane NADPH oxidases (NOX) and the mitochondrial ETC generate $\mathrm{O}_{2}{ }^{\bullet-}$ that can be converted to $\mathrm{ONOO}^{-}$in presence of $\mathrm{NO}$, or can be converted to $\mathrm{H}_{2} \mathrm{O}_{2}$ by superoxide dismutase (SOD). Peroxisomes, endoplasmic reticulum (ER), and mitochondrial monoamine oxidase (MAO) also contribute to $\mathrm{H}_{2} \mathrm{O}_{2}$ production. Catalase (CAT), glutathione peroxidase (GPx), and peroxiredoxin ( Prx) remove $\mathrm{H}_{2} \mathrm{O}_{2}$; otherwise, metal-catalyzed Fenton reactions generate ${ }^{\bullet} \mathrm{OH}$ that oxidizes cellular biomolecules.

\subsection{Biology of Reactive Species}

Under physiological conditions, RS play key roles on critical pathways within the cell acting as signaling molecules in cell survival and differentiation, cell adhesion, immune responses, regulation of vascular tone, synaptic plasticity, and programmed cell death, among others [12,24]. When RS production becomes dysregulated, these oxidation processes may lead to permanent damage, followed by cell death. Considering the dual role of RS, their cellular concentration must be tightly regulated in order to maintain redox homeostasis, hence, cells possess different antioxidant mechanisms.

Superoxide anion $\left(\mathrm{O}_{2}{ }^{--}\right)$is formed by a one-electron reduction of molecular oxygen. This process widely occurs via enzymatic reaction, catalyzed by NOXs [25,26] and xanthine oxidases [27]; via non-enzymatic electron transfer reactions such as the semiquinone in the mitochondrial ETC [28]; or via "auto-oxidation" reactions of non-radical compounds catalyzed by transition metals; e.g., dopamine (DA) or cysteine (Cys) [29]. The major physiological role attributed to superoxide is to kill foreign organisms in phagocytic cells, known as the respiratory burst of the immune system [30,31]. In addition to pathogen defense, superoxide may also control cell growth and vasoconstriction [32]. Increased levels of $\mathrm{O}_{2}{ }^{--}$can damage proteins containing iron-sulfur clusters [33] releasing free iron $\left(\mathrm{Fe}^{2+}\right)$, or react with molecules such as catecholamines to deactivate them [34]. To prevent the superoxide toxic effect, aerobic organisms possess different isoforms of superoxide scavenging enzymes, superoxide dismutase (SOD), that catalyze superoxide dismutation into $\mathrm{H}_{2} \mathrm{O}_{2}$ and molecular oxygen [35] (Figure 1).

Hydrogen peroxide $\left(\mathrm{H}_{2} \mathrm{O}_{2}\right)$ is an important redox signaling molecule [36]. Produced by SOD from superoxide, at physiological concentrations, $\mathrm{H}_{2} \mathrm{O}_{2}$ is capable of reversible oxidation of proteins, triggering different cellular processes such as proliferation, migration, differentiation, or angiogenesis [36]. $\mathrm{H}_{2} \mathrm{O}_{2}$ intracellular concentrations can be reduced by the action of catalase (CAT), peroxiredoxin (Prx), or glutathione peroxidase (GPx) [37] (Figure 1); otherwise, $\mathrm{H}_{2} \mathrm{O}_{2}$ redox-mediated signaling 
predominantly involves the reaction with thiolate (S-) from cysteine (Cys) residues to form a sulfenate $\left(\mathrm{SO}^{-}\right)$that can form intra- or inter-molecular disulfide bonds (SS) in the presence of other thiols, thus inducing protein modifications that alter its function. [38] These oxidized forms can be reversed by thioredoxins ( $\operatorname{Tr} x)$ or glutaredoxins (Grx), ensuring a reversible signal transduction mechanism. Sulfenate can be further oxidized to sulfinate $\left(\mathrm{SO}_{2}{ }^{-}\right)$, which can be reduced by sulfiredoxin (Srx) [39]; however, excessive $\mathrm{H}_{2} \mathrm{O}_{2}$ concentrations further oxidize these proteins to sulfonate $\left(\mathrm{SO}_{3}{ }^{-}\right)$, leading to irreversible oxidation of biomolecules and $\mathrm{H}_{2} \mathrm{O}_{2}$-mediated toxicity [38] (Figure 2).

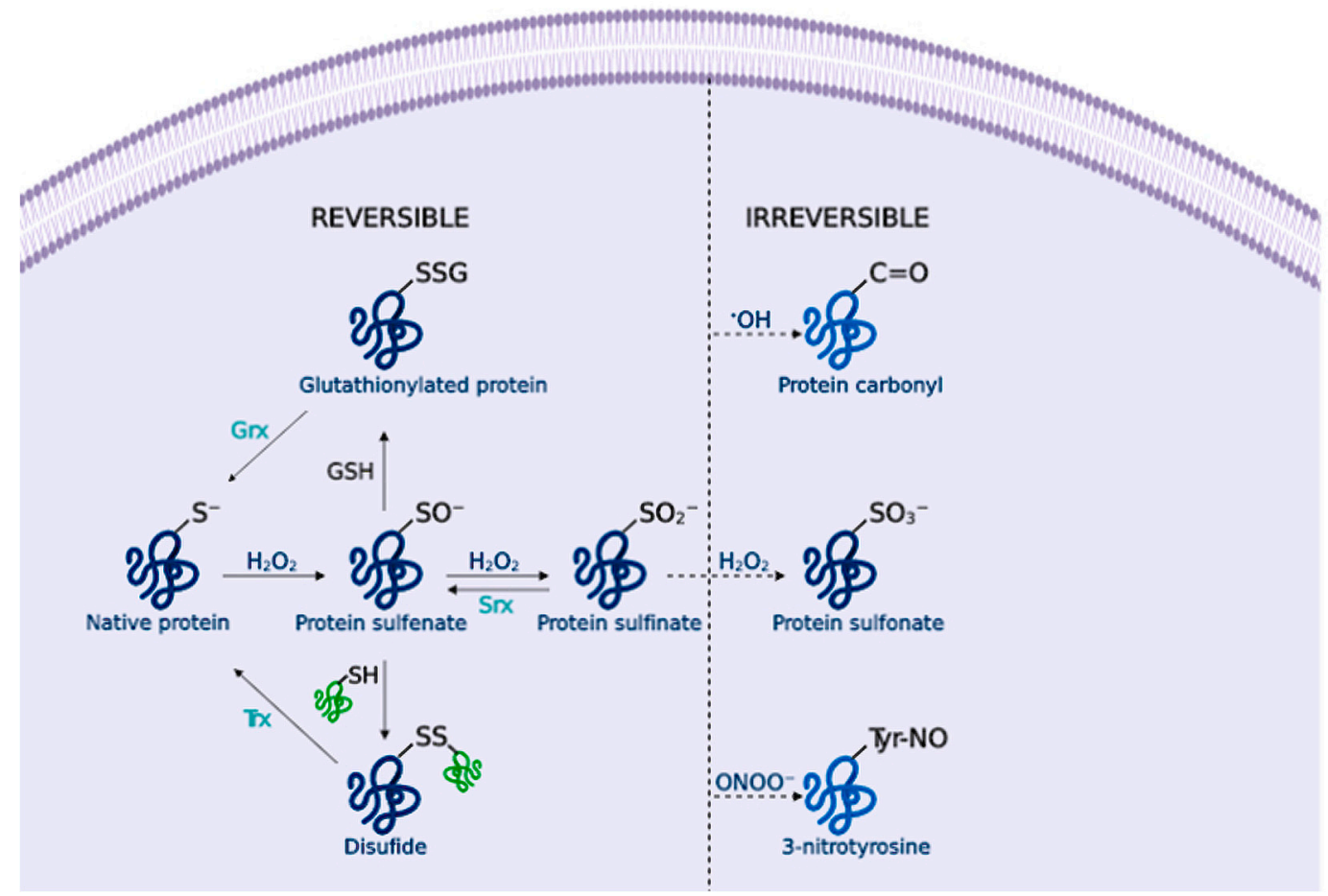

Figure 2. Cysteine redox modification by $\mathrm{H}_{2} \mathrm{O}_{2}$. Low $\mathrm{H}_{2} \mathrm{O}_{2}$ concentrations lead to sulfenates $\left(\mathrm{SO}^{-}\right)$ formation that can form disulfide (SS) or glutathionylated proteins (SSG), and sulfinates $\left(\mathrm{SO}_{2}{ }^{-}\right.$). These modifications can be reversed by thioredoxins (Trx), glutaredoxins (Grx) or sulfiredoxins (Srx). Under OS, the formation of sulfonate $\left(\mathrm{SO}_{3}{ }^{-}\right)$leads to irreversible damage. Likewise, amino acid oxidation by ${ }^{\bullet} \mathrm{OH}$ or $\mathrm{ONOO}^{-}$forms protein carbonyls and 3-nitrotyrosine residues that alter the protein function.

Hydroxyl radical $\left({ }^{\bullet} \mathrm{OH}\right)$ is formed from $\mathrm{H}_{2} \mathrm{O}_{2}$ by metal-catalyzed $\left(\mathrm{Fe}^{2+}\right.$ or $\left.\mathrm{Cu}^{+}\right)$Fenton reactions [40]. Additionally, superoxide can interact with $\mathrm{H}_{2} \mathrm{O}_{2}$ to undergo a Haber-Weiss reaction catalyzed by a metal ion to form ${ }^{\bullet} \mathrm{OH}[41]$. $^{\bullet} \mathrm{OH}$ is extremely reactive, thus it reacts close to its formation site, and indiscriminately oxidizes lipids, proteins and DNA, causing severe cellular damage [42] (Figure 1). For example, ${ }^{\bullet} \mathrm{OH}$ is able to directly oxidize amino acid side chains (via metal-catalyzed reactions), or cause protein backbone cleavage, leading to the irreversible formation of carbonyl groups [43] (Figure 2).

Nitric oxide (NO) is endogenously synthesized by nitric oxide synthases (NOS) from L-arginine in endothelial cells, neurons, and macrophages, among others. NO is important for several physiological processes, including neurotransmission, synaptic plasticity in the central nervous system (CNS), and immune regulation [44]. RNS overproduction may lead to nitrosylation reactions on proteins, altering their structure and function [45]. NO toxicity greatly increases upon reaction with $\mathrm{O}_{2}{ }^{\bullet-}$, as it produces peroxynitrite $\left(\mathrm{ONOO}^{-}\right)$[46], a potent pro-inflammatory and cytotoxic molecule $[47,48]$. $\mathrm{ONOO}^{-}$is highly reactive and can oxidize lipids [49], DNA [50], and methionine and tyrosine protein residues [51] (Figure 2). Besides, $\mathrm{ONOO}^{-}$is able to nitrate $\mathrm{SOD}$, thus promoting $\mathrm{O}_{2}{ }^{\bullet-}$ accumulation and damage [52]. 


\subsection{Signalling Pathways and Oxidative Stress}

In addition to the aforementioned functions, RS are involved in a plethora of signal transduction pathways. They play important roles as secondary messengers in cell growth, differentiation, and proliferation $[53,54]$. Supporting this observation, there is a large number of redox-sensitive proteins in cells [55]. Growth factors bound to tyrosine kinase receptors increase intracellular RS that are essential for downstream signaling events [56]. $\mathrm{H}_{2} \mathrm{O}_{2}$ can target Cys residues at the active sites of protein tyrosine phosphatases [57], playing an important role in the modulation of mitogen-activated protein kinases (MAPKs) signaling pathways. As a consequence, different pathways are activated, such as the phosphatidylinositol 3-kinase (PI3K)/Akt pathway [58], the extracellular-regulated kinases (ERKs), the c-Jun N-terminal kinases (JNKs), or the p38-MAPK cellular pathways [12].

In addition to the activation of signaling pathways, cells have several mechanisms to face changes in RS concentration. This involves activation of nuclear transcription factors, such as the activator protein 1 (AP-1) transcription factor, important for cell growth and differentiation [59], or the hypoxia-inducible factors (HIFs), responsible for the cell adaptation to low oxygen; both factors are degraded in a ROS-dependent manner [60].

A primary defense cellular mechanism against OS is the antioxidant Nrf2-ARE pathway that regulates the expression of the phase II antioxidant response enzymes [61,62]. Under normal conditions, Nrf2 is sequestered in the cytosol by Keap1 (a Kelch-like erythroid cell-derived protein with CNC homology (ECH)-associated protein 1), which is an adaptor protein for a Cullin 3 (Cul3) scaffold protein of Nrf2 ubiquitin ligase (E3) that promotes Nrf2 ubiquitination and degradation via the proteasome [63]. In the presence of exacerbated OS, key Cys residues at Keap1 are selectively oxidized [64,65], leading to a conformational change in Keap1 that prevents Nrf2 ubiquitination. Then, Nrf2 cytosolic concentration increases and it is translocated to the nucleus, where it binds to the ARE sequences promoting the expression of phase II enzymes. Moreover, the Nrf2-ARE pathway indirectly modulates other pathways, through crosstalk, like the Nuclear factor-kappa B (NF-kB) pathway.

Among the antioxidant enzymes regulated by the Nrf2-ARE pathway, SODs catalyze $\mathrm{O}_{2}{ }^{\bullet-}$ conversion to $\mathrm{H}_{2} \mathrm{O}_{2}$, which can be further removed by the action of GPx. PRXs are thiol-dependent peroxidases that catalyze the reduction of $\mathrm{H}_{2} \mathrm{O}_{2}$, organic hydroperoxides, and peroxynitrite [66] (Figure 1). Heme oxygenase-1 (HO-1), responsible for the degradation of the pro-oxidant heme group, releasing carbon monoxide (CO), biliverdin, and free iron.

Amongst non-enzymatic antioxidant systems, glutathione (GSH) is the most important antioxidant and redox buffer of the cell. Nrf2 target genes are involved in the synthesis of GSH: glutamate-cysteine ligase (GCL), glutathione reductase (GR) and glutathione S-transferase (GST). GSH can act as a direct antioxidant (by reaction with $\mathrm{O}_{2}{ }^{\bullet-}$ and ${ }^{\bullet} \mathrm{OH}$ ), transport and store cysteines, and it acts as an electron donor and maintains the redox potential in cells [67] (Figure 2).

$\mathrm{NF}-\mathrm{KB}$ is another pro-survival transcription factor activated by ROS that regulates several cellular defense mechanisms, such as cellular survival (transcription of anti-apoptotic proteins and inhibition of caspase-dependent cell death pathways), growth, and differentiation, and it is a master regulator of inflammation [68]. Under normal conditions, NF- $\mathrm{kB}$ is repressed at the cytosol by its inhibitor (IKB) and it is subjected to a complex regulation [69]. RS regulation of the NF-KB pathway has different outcomes depending on the cellular localization. In the cytoplasm, ROS promote I $\kappa B$ phosphorylation and subsequent NF- $\mathrm{KB}$ translocation to the nucleus to activate the proinflammatory signaling pathways; in contrast, RS may inactivate NF-kB by inhibiting its binding to DNA in the nucleus [70].

\subsection{Oxidative Stress-Driven Neurodegeneration}

The progression of age-related NDDs decreases the ability of cells to maintain redox homeostasis, promoting the accumulation of RS and neuronal injury. In addition to oxidative damage to biomolecules, RS toxicity in neurons contributes also to mitochondrial dysfunction [71], glial cells activation, protein misfolding and aggregation, leading, finally, to cellular apoptosis [72]; hence, OS damage promotes neurodegeneration. Low levels of RS enhance selective removal of damaged mitochondria by 
mitophagy [73], while high levels of RS can trigger mitochondrial permeability transition pore (mPTP) opening, leading to mitochondrial depolarization, loss of ATP production and $\mathrm{Ca}^{2+}$ levels elevation [74]; thus, OS contributes to cellular apoptosis, necrotic cell death, and ferroptosis [75] in NDDs [76]. RS can also activate matrix metalloproteinases, contributing to the blood-brain barrier (BBB) disruption [77], facilitating neurotoxic blood-derived products, and entry of peripheral inflammatory cells.

Oxidative damage occurs in all aerobic cells, yet the brain is particularly susceptible to OS [78]. Firstly, the brain is a highly energy-demanding tissue. It consumes about $20 \%$ of total oxygen, necessary to generate ATP to maintain all the openings and closings of ion channels associated with the propagation of action potentials and neurosecretion [29]. Other factors that contribute to brain vulnerability are:

- Mitochondrial DNA accumulates mutations during aging, therefore, mitochondria become less efficient in producing energy, and more efficient in generating free radicals. Neurons are highly dependent on oxidative phosphorylation, compared to other cells, and thus they become more sensitive to OS [7].

- Mitochondrial failure leads to a drop in ATP content, thus, other energy sources might become important, such as aerobic glycolysis or the mitochondrial tricarboxylic acid cycle. However, these energy-producing systems have been demonstrated to be dysregulated in NDDs [79,80].

- Several neurotransmitters are auto-oxidizable. DA, L-DOPA, or norepinephrine can react with $\mathrm{O}_{2}$ to generate $\mathrm{O}_{2}{ }^{\bullet-}$ and quinones/semiquinones that can deplete GSH and react with protein Cys residues [81].

- High levels of iron are found throughout the brain, where iron serves as an essential cofactor for proteins involved in normal neuronal function (cytochrome P450, ferritin, components of the mitochondrial ETC); nevertheless, iron can catalyze free radical formation via a Fenton reaction causing damage [82].

- Neuronal membrane lipids, rich in polyunsaturated fatty acids, can readily undergo lipid peroxidation. Furthermore, peroxidation products are highly neurotoxic, e.g., 4-hydroxynonenal (HNE) can trigger mPTP opening, increase free $\mathrm{Ca}^{2+}$ levels, and favor glutamate toxicity $[83,84]$.

- MAO enzymes in the brain catalyze the oxidative deamination of biogenic amines, greatly increasing $\mathrm{H}_{2} \mathrm{O}_{2}$ content [20].

- Antioxidant defenses are relatively low and decrease during aging, as demonstrated for GSH content [85].

In addition to intrinsic brain vulnerability to OS, certain neuronal cells are particularly prone to oxidative damage, known as selective neuronal vulnerability [86,87]. As such, pyramidal, cholinergic and noradrenergic neurons from the hippocampal CA1 region [88], entorhinal cortex [89], locus coeruleus [90] and basal forebrain [91] are vulnerable to neurodegeneration in AD; PD is characterized by neurodegeneration of dopaminergic neurons in the substantia nigra pars compacta (SNpc) [92]; while motor neurons in the motor cortex and spinal cord primarily undergo cell death in ALS [93]. Different mechanisms have been proposed as factors responsible for the selective neuronal vulnerability, including: (i) elevation of $\mathrm{Ca}^{2+}$ cellular levels make neurons expressing calcium-buffering proteins less vulnerable than those lacking these proteins [94,95]; (ii) perturbation of energy demand and mitochondrial activity makes large axonal arbors more susceptible, as in the case of dopaminergic neurons in the (SNpc) [96]; (iii) different expression patterns of glutamate receptors make neurons more vulnerable or resistant to degeneration [97,98]. Other mechanisms, such as higher neuronal vulnerability to proteostasis alterations, or the increased expression of neurofilaments, which tend to aggregate in large neurons, have been described. However, precise mechanisms of neuronal vulnerability are yet to be defined $[1,87]$. 


\subsection{OS Induced Degeneration in $A D, P D$ and ALS}

Different studies have demonstrated that oxidative damage is increased in AD patients compared to elderly controls at the early stages of the disease [99]. Amyloid beta (A $\beta)$ and hyperphosphorylated-tau (P-tau) accumulation in $\mathrm{AD}$ increases OS, leading to mitochondrial dysfunction [100]. A $\beta$ plaques bind $\mathrm{Cu}^{2+}$ and $\mathrm{Fe}^{3+}$ ions, facilitating $\mathrm{H}_{2} \mathrm{O}_{2}$ decomposition and ${ }^{\bullet} \mathrm{OH}$ production [101]. In turn, $\mathrm{OS}$ might increase $\mathrm{A} \beta$ production and aggregation and facilitates tau phosphorylation and polymerization, thus forming a vicious cycle that promotes the initiation and progression of $\mathrm{AD}$.

OS is also a major pathophysiological mechanism in PD. The fact that mitochondrial complex I inhibitors such as 1-methyl-4-phenyl-1,2,3,6-tetrahydropyridine (MPTP) cause clinical parkinsonism reveals a close relationship between mitochondrial dysfunction and PD. The reduced activity of complex I in the SNpc of PD patients has been linked to excessive RS production and subsequent apoptosis [102,103]. In addition, genes responsible for familial PD affect mitochondrial function, increasing OS [104]. Other pieces of evidence are related to the finding of the depletion of GSH levels in the SNpc at the early stages of PD, and increased iron levels [105].

In familial ALS, $20 \%$ of the cases result from mutations in SOD1, leading to a toxic gain of function of the enzyme as it loses the active sites for $\mathrm{Cu}^{2+}$ that converts the enzyme into a pro-oxidant protein that participates in RS generation [106]. SOD1 mutations increase NOX2-dependent RS production, which may cause motor neuron death [107].

\section{Proteinopathy in NDDs}

The presence of characteristic aberrant protein aggregates, as a consequence of proteostasis deregulation, is a relevant aspect in NDDs pathophysiology $[108,109]$. Misfolded proteins are targeted for ubiquitin proteasome system (UPS) degradation, or chaperone-mediated autophagy (CMA) degradation when tagged with a KFERQ motif; however, when UPS and CMA capacity is overwhelmed, aggregation-prone proteins form inclusion bodies that are delivered to the macroautophagy system (generally known as autophagy) (Figure 3).

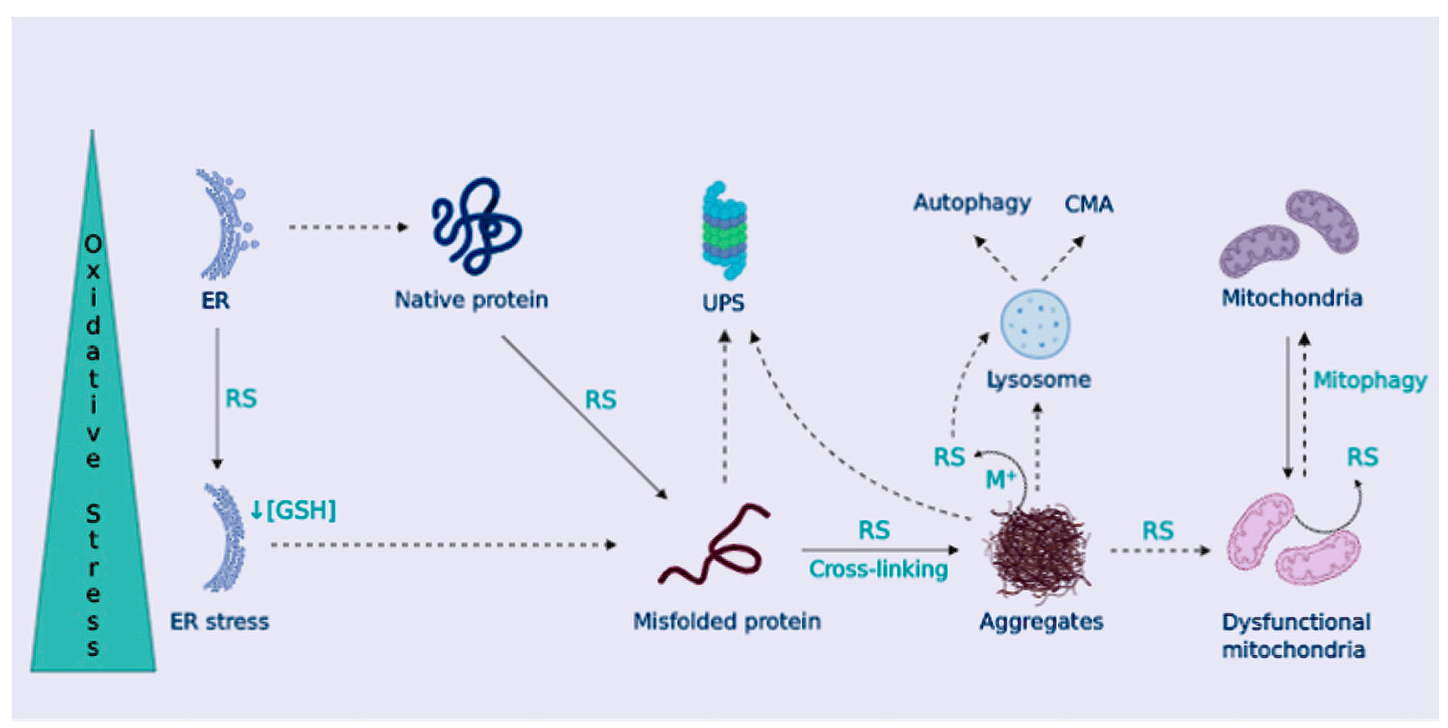

Figure 3. Cellular proteostasis is lost under OS. OS promotes protein misfolding and hydrophobic core exposure, leading to the formation of protein aggregates. Protein control systems, ubiquitin-proteasome system (UPS), chaperone-mediated autophagy (CMA), and macroautophagy (autophagy) are harnessed by OS, favoring protein aggregation. In addition, protein aggregates trap metal ions to produce RS-impairing mitophagy, leading to the accumulation of dysfunctional mitochondria. Also, the ER is damaged by OS, further promoting protein misfolding. 
Aberrant protein elimination is highly sensitive for neurons due to their inability to divide (and, therefore, to reduce their toxic aberrant aggregates content); in addition, protein aggregates need to be packaged in axons and dendrites to finally undergo a retrograde journey to the soma that is rich in lysosomes. During aging, molecular components and activity of UPS, CMA, and autophagy are down-regulated [110-112]. In addition, in many NDDs, misfolded proteins tend to aggregate in a $\beta$-sheet conformation that becomes neurotoxic, and they are able to propagate and further damage the activity of proteolytic systems.

\section{OS Contributes to Dampen Cellular Proteostasis}

OS contributes to protein misfolding and aggregation by several means. Proteasomal or lysosomal removal of damaged proteins may be altered by OS [113]. In turn, the accumulation of misfolded proteins leads to the formation of oligomers and higher aggregates that can interact with metal ions and catalyze RS production, as already described in NDDs [114]. Moreover, the formation of protein aggregates can impair mitochondrial bioenergetics or alter the removal of dysfunctional mitochondria through mitophagy $[115,116]$, leading to their accumulation, which further enhances RS generation and neuronal death (Figure 3). Characteristic protein aggregates of NDDs can also disrupt the mitochondria-ER association, leading to disrupted $\mathrm{Ca}^{2+}$ homeostasis and lipid metabolism, among others [117]. The ER is in charge of proper protein folding. OS disrupts ER function causing protein misfolding and ER stress that leads to the activation of the unfolded protein response (UPR) [118]. Also, given the high rate of disulfide bond formation during protein folding in the ER, ER stress contributes to OS by depleting GSH content [119]. In NDDs, activation of the UPR has been widely described, suggesting a role for ER stress in neurodegeneration [120] (Figure 3).

OS also influences protein function and folding by several pathways as a result of the direct reaction of RS with them. As such, NO can form RNS that can nitrate protein tyrosine residues, modifying the protein structure and function [121]. Similarly, $\mathrm{H}_{2} \mathrm{O}_{2}$ mediates redox signaling via reversible protein oxidation [36]. Cys residues are prone to RS oxidation because they possess highly nucleophilic thiol groups, thus, several cellular antioxidant systems act as redox switches to preserve the protein pools [38]. In contrast, there are no systems that can reverse protein carbonylation ( ${ }^{\bullet} \mathrm{OH}$ oxidation), thus, protein carbonylation is normally used as an OS marker [122] (Figure 2). Protein carbonylation (at proline, threonine, lysine, and arginine residues [123]) leads to protein unfolding and exposure of the hydrophobic core, and consequently, decreased solubility. Oxidized proteins tend to interact to form insoluble protein aggregates [124] commonly observed in NDDs. Moreover, side reactions between a carbonyl group from a carbonylated protein with an amino acid from a second protein forms a Schiff-base that further contributes to protein aggregation [125]. Additional cross-linking reactions mediated by RS, like lipid peroxidation products, may take place, amplifying the aggregation processes [126].

The formation of aggregates composed of heavily oxidized proteins can inhibit proteasome activity [126], which may be responsible for the down-regulation of proteasomal activity observed during aging [126]. In this sense, it has been previously reported that there is a decline in the proteasome $26 S$ subunit activity caused by OS [127]. Other UPS components can also be altered by OS, e.g., ubiquitin ligases can be modified by S-glutathionylation [128] or S-nitrosylation [129], modifying their clearance capacity (Figure 3). OS can oxidize proteins, and this can promote damage to the proteasome, likewise, OS directly harness the proteasome system. Altogether, these alterations promote accumulation and aggregation of proteins, spreading the advance of NDDs [130,131].

In the context of NDDs, the removal of aggregated proteins via autophagy is critical [132]. Autophagy deficits are likely to contribute to neurodegeneration in various diseases [133] and enhance the aggregation of pathological proteins ( $\mathrm{A} \beta$ peptide and Tau in $\mathrm{AD}, \alpha$-synuclein in PD, and SOD1 and TAR DNA-binding protein 43 (TDP-43) in ALS). Basal redox-signaling up-regulates autophagy flux [134], indicating a pro-survival response to eliminate oxidized proteins and prevent OS-induced apoptosis, while excessive activation of autophagy promotes cellular death. Redox-sensitive autophagy 
proteins like p62 possess oxidizable Cys residues that increase autophagy flux upon oxidation [135]. Similarly, OS conditions intensify the removal of oxidized proteins through CMA by upregulating LAMP-2A levels [136]. OS can also destabilize lysosomes, impairing autophagy [137], which leads to the accumulation of cross-linked aggregates in the form of lipofuscin [138] (Figure 3). Nonetheless, the effect of chronic OS and impaired autophagy in NDDs still needs further investigation [139].

\section{Neuroinflammation in Neurodegeneration}

The immune response within the brain is a tightly regulated process constituted by different molecular and cellular mechanisms including immune cells, blood vessels, and molecular mediators [140]. Microglia and astrocytes, and also, peripherally derived T cells, macrophages, and dendritic cells inspect the healthy CNS for harmful agents [141].

To provide innate immunity, microglial cells express Toll-Like Receptor (TLRs), NOD-like receptors (NLRs), and scavenger receptors [142]. When microglial cells are triggered ("classical activation"), they release high levels of pro-inflammatory cytokines such as tumor necrosis factor $\alpha$ (TNF $\alpha)$, interleukin 1 beta (IL-1 $\beta$ ) and IL-6, and chemokines (such as monocyte chemoattractant protein-1, MCP-1), and they increase the expression of the inducible nitric oxide synthase (iNOS) and NOX enzymes [143] (Figure 4). Following classical activation, microglia switches to an "alternative activation" that participates in inflammation resolution and tissue repair. These microglial cells are characterized by branched processes, and they release anti-inflammatory cytokines (IL-10 or IL-4), neurotrophic factors, and up-regulate molecular markers such as Arginase- 1 and transforming growth factor beta (TGF $\beta)$ [144].

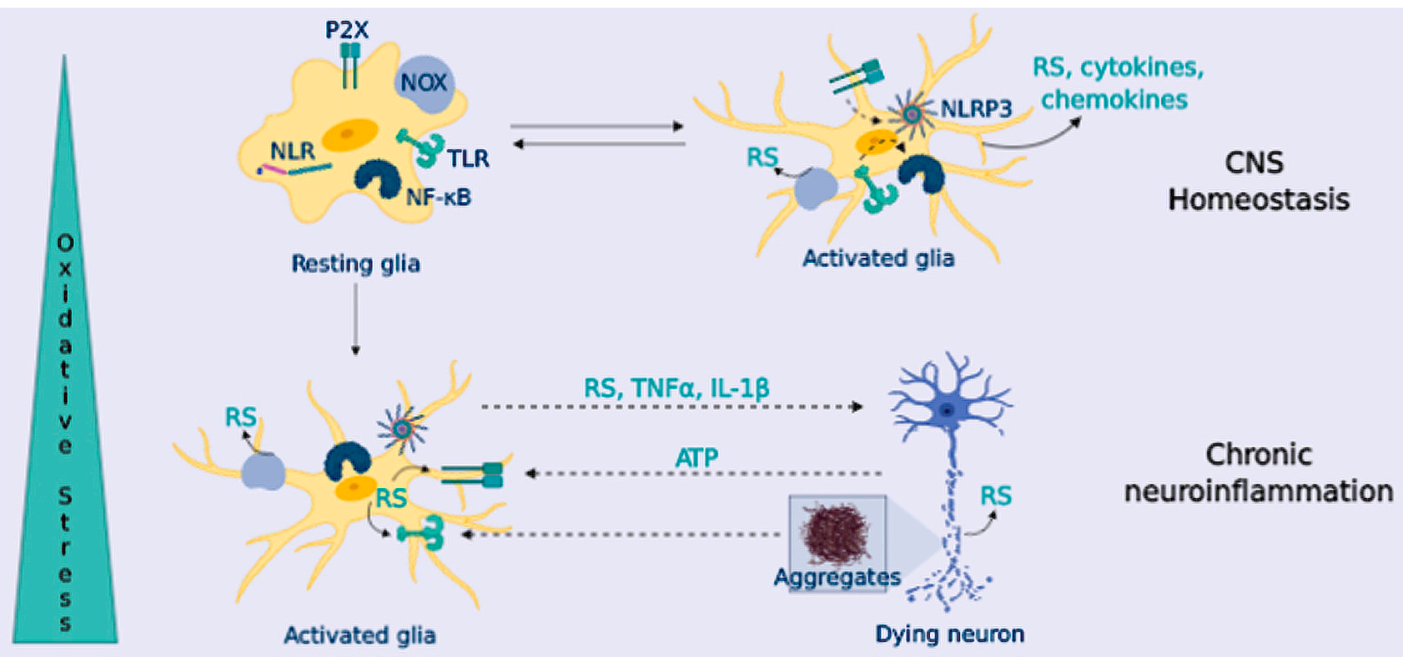

Figure 4. OS triggers chronic neuroinflammation, promoting neurodegeneration. Glial cells express TLR and NLR that sense harmful agents. Glial activation through TLR triggers the NF- $\mathrm{kB}$ signaling pathway and NLR like ligand-gated ionotropic purinergic receptor (P2X) that triggers NLRP3 signaling, promoting cytokine release, and also chemokines and RS (from NOX and iNOS enzymes). In healthy CNS, glial cells resolve the inflammatory response; in NDDs, the presence of protein aggregates and factors released from dying neurons leads to a sustained glial activation that contributes to neuronal demise.

Astrocytes are important for the formation of neuronal synapses, energy and metabolic support, and regulation of BBB permeability [145]. In the injured CNS, astrocytes become reactive, migrate to the damaged site, and form the glial scar [146]. Astrocytes also respond to inflammatory stimuli in the CNS. They express TLRs and scavenger receptors in their membrane, and they release pro-inflammatory mediators when stimulated with cytokines released by microglia $[142,147]$. Neuronal regions with 
a lower density of astrocytes are more susceptible to oxidative damage, as astrocytes are thought to clear-off RS in the environment [148].

\section{OS and Neuroinflammation}

RS are key second messengers in the innate and adaptive immune response, however, RS overproduction may lead to a sustained activation of the inflammatory response in immune cells, causing tissue damage and pathology [149] (Figure 4). In the innate immune response, mitochondria-derived RS can act as signaling molecules to up-regulate pro-inflammatory cytokine production [150]; in turn, these cytokines can cause RS up-regulation upon activation of iNOS (hence, $\mathrm{NO}$ excess) and $\mathrm{NOX}\left(\mathrm{O}_{2}{ }^{\bullet-}\right)$. Besides, $\mathrm{RS}$ are important for the activation of PRRs signaling pathways, [151]; likewise, NOX-derived and mitochondrial RS can activate the inflammasome component nucleotide-binding domain leucine-rich repeat and the pyrin domain containing receptor 3 (NLRP3) [152], increasing the production of IL-1 $\beta$ (Figure 4).

In addition to the microglial-astrocyte crosstalk, neurons also participate in the immune response. Neurons sense glial-released pro-inflammatory factors; in response, they can release inhibitory factors to resolve inflammation, or they can further activate glial PRRs receptors through the release of damage-associated molecular patterns (DAMPs), such as ATP or DNA [153] (Figure 4). In addition to the microglial-astrocyte crosstalk, neurons also participate in the immune response. Neurons sense glial-released pro-inflammatory factors; in response, they can release inhibitory factors to resolve inflammation, or they can further activate glial PRRs receptors through the release of damage-associated molecular patterns (DAMPs), such as ATP or DNA [153] (Figure 4). In fact, neuron-glial crosstalk is necessary for the correct function of glial cells and neurons, significantly contributing to brain homeostasis [154]. Communication between glial cells and neurons is mediated by a plethora of signals and receptors, including neurotransmitters (glutamate, GABA, or serotonin) and their receptors. It also includes the purinergic and adenosine signaling of different chemokines including fractalkine (a chemokine produced by neurons that signals directly in microglia) [155]. The complement system is also present in neurons and glia, and this communication is reported to be altered in NDDs [156]. The interconnection between neurons and the immune system has been concisely reviewed by Marinelli et al. [154].

Under some circumstances, glial cells undergo an uncontrolled activation, leading to chronic neuroinflammation that triggers an exaggerated inflammatory response, the release of neurotoxic factors and, finally, to neuronal loss (e.g., chronic exposure to TNF $\alpha$ can cause neuronal death) [157] (Figure 4). Given the limited microglia replication and turnover, microglial cells (and astrocytes) change to a more inflammatory phenotype, known as microglial priming, during aging [158]. In NDDs, there is increased microglial priming that enhances the neuro-inflammatory-derived toxicity and boosts neurodegeneration [159]. In addition, intrinsic characteristics of NDDs, like OS and the presence of protein aggregates, lead to a sustained microglial activation that becomes deleterious.

\section{Pathological Crosstalk in Neurodegeneration}

In previous sections, we have addressed the harmful role of OS, protein aggregation, and neuroinflammation in NDDs. However, it is necessary to highlight the interconnection among these factors as key drivers of neurodegeneration at the early stages of disease development.

(I) OS is responsible for the oxidative damage to cell biomolecules and RS are essential to the initiation of immune responses. Also, RS activate redox-sensitive transcription factors such as NF- $\mathrm{B}$, crucial for the neuroinflammatory response. Chronic NF- $\kappa$ B activation leads to sustained microglial activation [160] that increases OS. OS can compromise BBB integrity, favoring the infiltration of peripheral immune cells, contributing to neuroinflammation and neurodegeneration. Protein oxidation by carbonylation cannot be reversed and it leads to protein unfolding, hydrophobic residue exposure, and decreased solubility, thus enhancing the risk for protein aggregation. Furthermore, additional cross-linking reactions favor the formation of protein aggregates and further extend 
oxidative damage [125]. Various cellular systems related to the removal of misfolded proteins and protein aggregates that control cellular proteostasis are dysregulated. OS can destabilize lysosomes, impairing autophagy [137] through Fenton reactions that lead to lysosomal iron-mediated rupture, and can also alter the UPS (Figure 3).

(II) In NDDs characterized by the presence of aberrant protein aggregates, these aggregates can become RS sources themselves as they tend to coordinate metal ions, increasing radical production via Fenton chemistry. Moreover, aberrant protein aggregates act as DAMPs signals on microglial cells, triggering the inflammatory response [161]. In NDDS, the proteolytic systems become deficient, and misfolded proteins continue to aggregate, promoting a sustained microglial activation that leads to chronic neuroinflammation.

(III) Glial inflammatory activation contributes to OS by increasing the expression of iNOS and NOX enzymes and promotes endoplasmic reticulum stress that aggravates protein misfolding [162]. Compelling pieces of evidences have demonstrated that the release of cytokines, chemokines, and RS from activated glial cells harnesses autophagy when it becomes sustained [163]. In addition to the relation with OS, neuroinflammation further enhances neurodegeneration by altering cellular proteostasis, and it has been demonstrated that IL-1 $\beta$ and IL-6 can block autophagy in microglia [164]. Consequently, chronic neuroinflammation leads to autophagy failure, increasing the accumulation of protein aggregates, that, in turn, activate glial cells, initiating a positive feedback loop that contributes to neurodegeneration. Finally, these factors induce neuronal damage, and eventually, neuronal death. Dying neurons release different factors such as ATP that activate P2X microglial receptors triggering NLRP3 inflammasome, and they also release RS or glutamate contributing to excitotoxicity. Due to the cell-cell communication, feedback loops are established, spreading the damage that leads to neurodegeneration (Figure 4).

\subsection{Alzheimer's Disease}

$\mathrm{AD}$ is a chronic, irreversible, and fatal NDD that affects 46.8 million people worldwide, being the most common cause of dementia during aging. AD is characterized by progressive cognitive impairment and memory loss and two major hallmarks, extracellular amyloid plaques, composed by aggregated $A \beta$ peptide, and intracellular neurofibrillary tangles (NFTs), constituted by aberrant P-Tau [165]. Currently, $\mathrm{AD}$ is considered a multifactorial disease derived from a highly complex pathological network in which the initial causes remain elusive. Due to its complexity, the latest research hypotheses are questioning if these aggregates are a physiological response to pre-existing homeostasis deregulation that induces their production in response to a previous toxic insult. In this line, recent evidence points to a combination of pathological events at the early stages of the disease, and the interconnection among them, as potential effectors to initiate the complex cascade of events leading to AD development [166]. Therefore, in addition to protein aggregation, several pathological pathways are currently being investigated, including mitochondrial failure [167], OS [168], chronic neuroinflammation [169], and proteostasis dysregulation $[170,171]$.

As previously described, OS is known to progressively increase during aging, being a key factor in the neuronal loss observed in $\mathrm{AD}$ as a consequence of mitochondrial dysfunction, metal dyshomeostasis, and defective antioxidant defenses [172]. Mitochondrial failure is an AD pathological hallmark and the main source of RS leading to the oxidation of protein, lipids, and nucleic acids. These oxidized products have been found in the post-mortem brains of AD patients [173] together with a decreased activity of mitochondrial cytochrome c oxidase [174], complex IV of the ETC. Interestingly, ROS and RNS overproduction are linked to $\mathrm{A} \beta$ production and toxicity and, in turn, $\mathrm{A} \beta$ increases RS, mitochondrial dysfunction, and cytosolic $\mathrm{Ca}^{2+}$ imbalance prior to amyloid plaques' establishment [175]. These detrimental effects have been recently related to the $\mathrm{A} \beta$ ability to inhibit the cytochrome $c$ oxidase [176], inducing energy depletion and mitochondrial failure. Furthermore, OS impairs the low-density lipoprotein receptor-related protein 1 (LRP1), a receptor involved in A $\beta$ endocytosis for further clearance, oxidizing it and impairing its activity facilitating A $\beta$ accumulation [177]. A 60\% 
increase in oxidized LRP1 has been observed in the hippocampus of AD patients compared to age-matched controls. Furthermore, as previously depicted, $\mathrm{A} \beta$ oligomers and protofibrils are able to coordinate $\mathrm{Cu}^{2+}, \mathrm{Zn}^{2+}$ and $\mathrm{Fe}^{2+}$ metal ions increasing RS production via Fenton chemistry [114] and highly contributing to OS damage.

OS has also been related to tau hyperphosphorylation by a number of different pathways. OS increases the expression of regulator of Calcineurin 1 (RCAN1), the natural repressor of calcineurin (a phosphatase that dephosphorylates tau), augmenting tau phosphorylation [178]. Additionally, high RCAN1 levels increase glycogen synthase $3 \beta$ (GSK-3 $\beta$ ) expression, one of the most important kinases related to tau hyperphosphorylation, accelerating the formation of P-Tau and NFTs [179]. OS also accelerates P-Tau aggregation by the oxidation of a Cys residue on tau [180] or by nitration, S-nitrosylation and oxidation of methionine residues [181], increasing its aggregation and self-assembly capacity. Additionally, overactive GSK-3 $\beta$ facilitates A $\beta$ formation and aggregation [182], induces OS, and participates in the activation of pro-inflammatory pathways [183]. A mayor role of GSK-3 $\beta$ on RS production in AD pathology is its ability to inhibit the Nrf2-ARE anti-oxidant pathway. GSK-3 $\beta$ phosphorylates Nrf2 at the Neh6 degron domain, creating a recognition site for $\beta-\operatorname{TrCP}$, an E3 ligase adaptor that facilitates Nrf2 ubiquination and its proteasomal degradation [184]. Under pathological AD conditions, GSK- $3 \beta$ activity has been widely reported to be increased, thus, it decreases Nrf2-ARE pathway activation to exacerbate OS.

Chronic neuroinflammation plays a key role in AD onset and development. OS pathologically induces glial activation, mainly microgliosis and astrogliosis. Compelling evidence reports the apparition of increased levels of proinflammatory cytokines in the blood, cerebrospinal fluid (CSF), and post-mortem brain tissues of $\mathrm{AD}$ patients [185,186]. OS, oxidized biomolecules, and $\mathrm{A} \beta$ [187] are known to activate microglia, initiating the proinflammatory response. Once activated, microglia activate the expression different proinflammatory factors, including iNOS and NOX, that produce high amounts of RS and proinflammatory cytokines such as $\mathrm{TNF} \alpha$, and different proinflammatory interleukins (IL-1 $\beta$ or IL-18). In turn, NO liberated by iNOS is rapidly transformed into $\mathrm{ONOO}^{-}$that readily nitrates $A \beta$, augmenting its self-aggregation capacity and toxicity [188]. Importantly, nitrated $A \beta$ is the main component of amyloid plaques [189]. $A \beta$ is able to activate the scavenger receptor CD36, stimulating sterile inflammation that promotes TLR4 and TLR6 activation to initiate the NF- $\mathrm{KB}$ proinflammatory pathway [190], further increasing OS and proinflammatory factors' release. In turn, CD36 promotes $A \beta$ oligomerization, acting as a priming signal for NLRP3 activation that liberates high amounts of IL-1 $\beta$ [191]. Finally, IL-1 $\beta$ increases p38-MAPK and GSK-3 $\beta$ activities, promoting tau hyperphosphorylation [192].

Considering proteostasis, the formation and accumulation of misfolded proteins have been associated with a dysregulation of these clearance pathways, including UPS [130], CMA, and autophagy processes $[193,194]$. Considering the UPS system, it was described that $A \beta$ is able to inhibit this clearance system, promoting further $A \beta$ and P-Tau accumulation [195]. Under OS conditions, essential proteins of the UPS are oxidized and lose their functions, such as the ubiquitin carboxy-terminal hydrolase L1 (UCHL1) [196,197], leading to increased levels of polyubiquitinated proteins, dysfunctional UPS, and accumulation of aberrant aggregates [198]. Moreover, OS can damage proteasome 26S, eliminating the two initial parts of the complex, preventing its capacity to process ubiquitinated proteins [130], and thus, accelerating the accumulation of abnormal proteins. Once accumulated, $A \beta$ is prone to be processed by autophagy under OS pathological conditions [199]; however, its accumulation impairs the autophagosome-lysosome fusion, promoting the accumulation of non-processed vesicles at dystrophic neurites [200]. Additionally, hyperphosphorylated tau has been found to co-localize with LC3-II and p62 in AD patients, indicating a potential effort to eliminate these aberrant aggregates [201]. However, P-Tau also disrupts axonal transport, contributing to autophagosome accumulation in AD [202]. Furthermore, OS excessively inhibits autophagy via mTOR (mammalian target of rapamycin) [203,204]. Thus, the interconnection between OS, chronic neuroinflammation, and proteostasis failure can create 
a highly toxic environment for neurons [80], and, more importantly, the positive feedback loops generated accelerate the advance of the disease over time.

\subsection{Parkinson's Disease}

$\mathrm{PD}$ is characterized by the progressive degeneration of dopaminergic neurons in the $\mathrm{SNpc}$, as well as other brain regions, including the locus coeruleus and the nucleus basalis of Meynert [205]. The loss of dopaminergic signaling is responsible for the cardinal motor symptoms observed in the disease. The most prominent PD pathological hallmark is the presence of cytoplasmic inclusions composed of $\alpha$-synuclein proteins, termed Lewy bodies [206]. Although PD etiology is not fully understood, environmental and/or genetic mutations, related to the familial forms, have been described [207,208]. From a molecular point of view, OS has been recognized as a principal mechanism leading to neuronal death in PD $[209,210]$. OS sources in PD include mitochondrial dysfunction, neuroinflammation, DA metabolism, and iron dysregulation; at the same time, mechanisms that control cellular homeostasis like the UPS and mitophagy are altered by OS and can, in turn, enhance RS production. The interplay among these factors generates a complex network that promotes neuronal demise.

Analysis of post-mortem brains shows that oxidative damage is present in PD, as revealed by the presence of HNE [211], protein carbonyls [212], and DNA oxidation products [213]. Dopaminergic neurons are prone to OS due to DA metabolism by MAO and auto-oxidation that produces RS within the cell. Likewise, DA auto-oxidation generates quinone intermediates that can deplete cellular GSH and modify PD related proteins such as $\alpha$-synuclein, contributing to neurodegeneration [209]. In fact, reduced GSH levels are decreased in the SNpc of PD brains compared to age-matched controls [214]. GSH downregulation induces decreased mitochondrial complex I activity and higher neuronal vulnerability to OS, leading to nigrostriatal neurodegeneration [215]. Moreover, PD brains contain higher levels of iron in the SNpc compared to aged matched controls, contributing to the pathogenesis [216]. Lastly, dysfunction of mitochondrial complex I in the SNpc has been linked to PD pathology [103]; it can enhance mitochondrial DNA mutations, abnormal mitochondrial $\mathrm{Ca}^{2+}$ homeostasis, and OS, and it can cause $\alpha$-synuclein aggregation [217]. Familial forms of PD caused by genetic mutations in DJ-1, PTEN-induced kinase 1 (PINK-1), parkin, and leucine-rich repeat kinase 2 (LRRK2) also impact the mitochondrial function, further evidencing the implication of OS in PD neurodegeneration.

The physiological role of $\alpha$-synuclein remains elusive; to the date, it has been associated with synaptic function, neurotransmitter release, vesicle trafficking, and synaptic plasticity [218]. This presynaptic protein has a predisposition to form fibrillary structures and aggregates, eventually leading to cell death. The proteasome, CMA, and autophagy can degrade $\alpha$-synuclein $[219,220]$; however, these systems are damaged in PD [221]. After OS damage, the proteasome impairment observed in PD [222] contributes to $\alpha$-synuclein aggregation; in turn, aggregated $\alpha$-synuclein further impairs proteasome activity [223].

Damaged CMA has also been linked to PD [224]. Interestingly, $\alpha$-synuclein is modified by oxidized DA, blocking its CMA degradation. Modified $\alpha$-synuclein also impairs the degradation of other substrates [225], suggesting a mechanism for selective dopaminergic neuronal degeneration in PD. Similar to $\alpha$-synuclein, mutant forms of UCHL1 and LRRK2 interact with the lysosomal membrane receptor LAMP2A and block the CMA pathway [226,227]. $\alpha$-synuclein accumulation can further harness the autophagy system [228]. Autophagy failure in PD is particularly important for mitochondrial control. Mitophagy is principally mediated by two proteins, PINK1 (a serine/threonine kinase) and parkin. In damaged mitochondria, PINK1 accumulates in the outer membrane, phosphorylates ubiquitin, and activates parkin E3 ligase activity $[229,230]$, finally leading to mitochondria ubiquitination by parkin and degradation by autophagy [231]. Mutations in these proteins cause deficient mitophagy [232]. Furthermore, the accumulation of damaged mitochondria enhances OS and contributes to apoptotic cell death. Additional complex interactions involve $\alpha$-synuclein aggregation [233]; however, the exact pathological mechanism requires further exploration. 
PD pathology is also exacerbated by neuroinflammation [234]. Microglia contribute to aggregated $\alpha$-synuclein clearance [235]. Upon the engulfment of $\alpha$-synuclein for degradation as a protective role, microglial cells are activated; however, chronic glial activation can contribute to neurodegeneration progression in PD [236]. Activated microglia are an important source of RS, and supporting this affirmation, elevated levels of iNOS and COX in the SNpc of PD patients have been observed [237]. In addition, increased levels of other toxic agents such as TNF $\alpha$ in the striatum, SNpc and cerebrospinal fluid [238], and inflammatory cytokines like IL-1 $\beta$, IL-2, IL-4 and Il-6 [239] have also been widely described in PD patients. Activated microglia intensify neuronal death, and in turn, dying neurons and the pro-inflammatory factors released by microglia and astrocytes amplify and perpetuate the chronic neuroinflammation, creating a toxic cycle intensifying and accelerating neurodegeneration.

\subsection{Amyotrophic Lateral Sclerosis}

ALS, known as the motor neuron disease, is characterized by progressive loss of motor neurons in the spinal cord, brainstem, and motor cortex [93]. Pathologically, the disease is characterized by the presence of cytoplasmic inclusions in degenerating neurons [240] accompanied by astrogliosis [241]. The cause of the disease largely remains unknown; in familial ALS ( $10 \%$ of the cases), $20 \%$ result from mutations in SOD1 [242]. Evidence indicates that mutant SOD1 does not lose its function; in contrast, a gain of toxic function has been associated with ALS, e.g., mutant SOD1 increases NOX2-dependent RS production reducing cell survival [107]. Mechanisms leading to neuronal degeneration in ALS are complex; protein aggregation, OS, mitochondrial dysfunction, neuroinflammation, and excitotoxicity have been described [243].

Focusing on OS, there is large evidence of increased OS in ALS pathogenesis. Increased protein carbonyl levels have been detected in spinal cords of sporadic cases [244], together with increased levels of 3-nitrotyrosine residues in spinal cords of sporadic and familial forms $[245,246]$ and CSF of patients with sporadic ALS [247]. In addition, augmented levels of 8-hydroxy-2'-deoxyguanosine (oxidative damage to DNA) [248] and HNE [249] were detected in ALS patients. Metal-catalyzed OS have been also linked to ALS pathogenesis [250]. The OS deleterious effect in ALS can be detrimental due to its interactions with other pathological pathways, including $\mathrm{Ca}^{2+}$ dyshomeostasis and excitotoxicity. In ALS patients, the following have been found: (i) elevated levels of excitatory amino acid present in CSF [251]; (ii) increased $\mathrm{Ca}^{2+}$ levels in motor nerve terminal [252]; (iii) loss of excitatory amino acid transporter 2 (EAAT2) in astrocytes, leading to increased extracellular glutamate concentration and neuronal excitotoxicity [253,254]; (iv) motor neurons that have scarce $\mathrm{Ca}^{2+}$ buffer systems and a high number of AMPA $\mathrm{Ca}^{2+}$-permeable receptors [255]. Altogether, these factors support the hypothesis that $\mathrm{Ca}^{2+}$-dependent excitotoxicity plays a central role in ALS pathogenesis [256]. Increased $\mathrm{Ca}^{2+}$ levels are buffered by mitochondria; however, during excitotoxicity, mitochondrial $\mathrm{Ca}^{2+}$ overload induces OS and cell death [257]. In turn, RS are able to trigger excitotoxicity [258], e.g., HNE in the spinal cords of ALS patients was responsible for induced damage to EEAT2 in astrocytes, causing excitotoxic motor neuron death [259].

ALS is also characterized by the presence of protein inclusions, and OS damage can contribute to protein misfolding and aggregation. TDP-43 was identified as a major component of ubiquitin positive inclusions in spinal cords of familial and sporadic ALS patients $[260,261]$; interestingly, they were not found in SOD1-familial cases [262]. TDP-43 localization is predominantly nuclear; conversely, in ALS, aggregates are located in the cytoplasm, leading to the hypothesis that cytoplasmic TDP-43 localization is toxic and induces cell death [263]. Pathological protein inclusions have been observed to be composed by other proteins, including SOD1 [264] and FUS (Fused in Sarcoma) [265]; nevertheless, these hallmarks are associated with gene mutations. TDP-43 and FUS are RNA-binding proteins, and they are rich in residues that can adapt an unfolded or aggregated state [240]; as such, aggregation in ALS can be related to a prion-like spreading of the disease [266], where one aggregated protein can sequester unfolded proteins to adopt the aggregated form. Likewise, the alteration of protein degradation pathways contributes to ALS pathophysiology. Ubiquitin presence exemplifies the 
involvement of UPS in protein aggregation [267,268]; indeed, proteasome inhibition in cellular models leads to increased TDP-43 levels [269]. Familial cases linked to UBQLN2 (ubiquilin 2) mutations provide another example of protein recycling dysfunction in ALS [270]. Also, different studies have reported autophagy dysregulation in motor neurons as a critical event in its pathophysiology [271,272].

Inflammation has also been related to ALS pathogenesis. Compelling evidence has demonstrated that levels of the pro-inflammatory cytokine IL-17A were increased in the spinal cords of sporadic and familial ALS cases [273], as well as levels of MCP-1 chemokine in the CSF [274]. Additional studies suggest a role for TLR/RAGE (receptor for advanced glycation end-products) signaling in ALS, e.g., increased expression of TLR2, TLR4, and RAGE was found in the spinal cords of ALS patients [275]; however, it is unclear to which extent neuroinflammation contributes to neurodegeneration. Degenerating motor neurons in ALS are enwrapped by astrogliosis. During the disease progression, astrocytes become chronically activated, they lose their neuroprotective role, and they release pro-inflammatory factors and provide a neurotoxic environment [276]. Changes in astrocyte function provide a link to the hypothesis of glutamate excitotoxicity in neuronal demise [241]. The ionotropic P2X7 receptor has been associated with neuroinflammation in ALS. P2X7 receptors are expressed in CNS cells [277], where they get activated by ATP to activate the NLRP3 inflammasome, exacerbating the microglial response and contributing to the pathogenesis of ALS [278].

\section{Nrf2-ARE Pathway as Therapeutic Strategy}

In order to prevent oxidative damage buildup, antioxidant therapies have long been pursued; however, given the involvement of RS in cellular signaling, as well as other potential causes, clinical studies with antioxidant therapies have failed in slowing or halting disease progression. As such, the up-regulation of endogenous antioxidant systems provides an alternative treatment option.

As previously described, the antioxidant Nrf2-ARE pathway is mediated by conformational changes in Keap1, leading to Nrf2 translocation into the nucleus, and expression of the phase II response enzymes (Figure 5). While Keap1 modification mostly occurs under OS conditions, or in the presence of targeted compounds, Nrf2 can be additionally modulated by several proteins. For instance, p62/SQSTM1 competitively binds to Keap1 to release Nrf2 when it accumulates in autophagy-deficient conditions [279]. Also, as earlier discussed, GSK-3 $\beta$ can phosphorylate Nrf2 serine residues, creating a recognition motif for $\beta$-TrCP, an E3 ligase adapter, that mediates Nrf2 ubiquitination and proteasomal degradation in a Keap1 independent manner [184].

Nrf2, considered the master regulator of the phase II response, regulates genes involved in OS down-regulation and the upregulation of antioxidant enzymes, such as SOD, GPx, Prx, Trx, and Srx (Figure 5). In the presence of high amounts of RS, Nrf2 also regulates the expression of enzymes involved in the "de novo" synthesis of GSH (GCL, GR, GST) to recover GSH levels and rapidly eliminate toxic species [280]. Nrf2 also regulates several proteins related to the healthy mitochondrial function, such as the mitochondrial ETC component mitochondrial complex associated (NDUFA4), to regulate ROS production in the damaged mitochondria [281].

The Nrf2-ARE pathway is also linked to inflammatory processes. HO-1 is one of the most important antioxidant and anti-inflammatory enzymes induced by the Nrf2-ARE pathway. Moreover, Nrf2 is closely linked to the pro-inflammatory NF-кB pathway; in fact, various Nrf2 inducers have demonstrated anti-inflammatory properties via inhibition of the NF- $\mathrm{B}$ pathway [282]. Several connections among the two pathways have been described, evidencing the finely balanced equilibrium; Keap1 inhibits IKK $\beta$ (the inhibitor of nuclear factor kappa-B kinase subunit beta) phosphorylation, thus blocking NF- $\mathrm{B}$ translocation to the nucleus, and down-regulates TNF $\alpha$ [283]. In turn, NF- $\mathrm{B}$ can repress Nrf2 signaling at the transcriptional level, as both factors compete for transcription co-activator binding protein (CREB binding protein, CBP) [284]. Also, NF-кB p65/relA subunit co-imports Keap1 to the nuclei to bind Nrf2 and promote its exportation to the cytosol and further degradation [285]. 
Additionally, the Nrf2-ARE pathway is important for cellular proteostasis. Autophagy adaptor proteins p62 and NDP52 are regulated by the Nrf2-ARE pathway [286,287]. Interestingly, they possess ubiquitin and LC3 binding sequences; thus, they are able to recruit ubiquitinated autophagy substrates to the autophagosome. Additional genes involved in cargo recognition, autophagosome formation, and autolysosome clearance are regulated by Nrf2 [288]. Likewise, Nrf2 regulates CMA through the modulation of LAMP-2A levels [289].

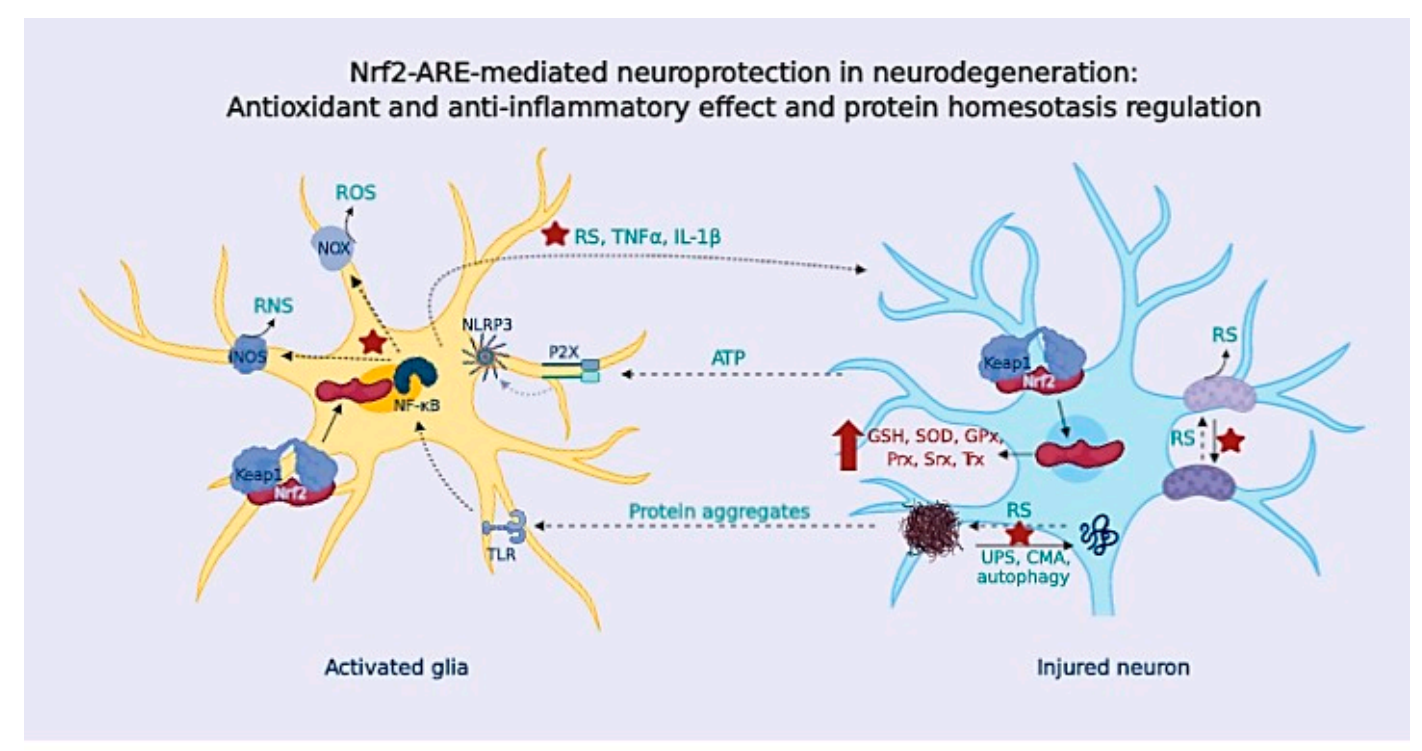

Figure 5. The Nrf2-ARE pathway provides neuroprotection in multiple ways. The activation of the Nrf2-ARE pathway increases the expression of antioxidant enzymes and GSH levels, thus preventing the damage to biomolecules, mitochondrial dysfunction, and neuronal apoptosis. Nrf2-ARE pathway upregulation prevents OS-driven protein misfolding and aggregation, and also stimulates the UPS and autophagy systems to control the cellular proteostasis. Additionally, the Nrf2-ARE pathway exerts anti-neuroinflammatory properties, induces the expression of the anti-inflammatory enzyme $\mathrm{HO}-1$, interferes with the transcription of the inflammatory NF- $\mathrm{kB}$ pathway, and down-regulates NOX and iNOS-derived RS. The antioxidant and anti-neuroinflammatory effect and protein homeostasis regulation mediated by the Nrf2-ARE pathway prevents neurodegeneration.

Thus, considering the large number of genes regulated by the phase II antioxidant response, the development of Nrf2 inducers is a highly interesting strategy in NDDs drug development. Compared to other antioxidant strategies, Nrf2 induction can regulate RS produced by mitochondria, cellular proteostasis, and neuroinflammation at the same time, recovering homeostasis. However, Nrf2 induction must be tightly regulated given that too potent an induction might be deleterious for cells, inducing toxicity and finally cellular death. Nonetheless, controlled chronic Nrf2 induction has already been demonstrated to be clinically efficacious in multiple sclerosis (MS), and it is under evaluation for other OS related diseases.

The Nrf2-ARE pathway is known to be dysregulated in several NDDs. From the above-outlined properties, Nrf2 induction has been considered a valuable strategy for developing drug candidates for the treatment of NDDs [290], as it can contribute to reducing OS, neuroinflammation, and protein aggregates present in these diseases [291,292]. Thus, targeting all these processes at the same time with an Nrf2 inducer may have a greater impact on the complex pathophysiology of NNDs. Given that the Nrf2-ARE pathway might be activated by different mechanisms, it raises the possibility to modulate the pathway via a diverse range of chemical compounds. Nrf2 up-regulation can be achieved either by direct Nrf2-Keap1 targeting or indirect modulation of connected pathways [293]. Regarding direct modulation of Nrf2-Keap1, diverse chemical compounds have been described as Nrf2 inducers, most of them being electrophilic compounds that can modify sulfhydryl groups on Keap1-cystein residues, 
while recent advances in the field have led to the development of protein-protein interaction inhibitors of the Nrf2-Keap1 interaction [294].

The interest of the Nrf2-ARE pathway as a suitable target to treat OS-related diseases has been demonstrated with the approval of the first Nrf2 inducer for the treatment of MS, dimethyl fumarate (DMF), in 2013 [295]. During the last years, novel structures have been developed aiming to obtain specific properties for the treatment of different complex diseases, including AD, PD, and ALS [291].

DMF was the first Nrf2 inducer approved for clinical application. It is an electrophilic compound that covalently binds to Cys residues at Keap1. DMF has been extensively evaluated as a repurposing treatment for $\mathrm{AD}, \mathrm{PD}$, and ALS with interesting results. Considering AD, DMF has demonstrated the ability to reduce neuroinflammation and improved the memory deficit in an in vivo model of neuroinflammation [296], decreasing cytokines' expression by inhibiting NF- $\mathrm{kB}$ nuclear translocation. Recently, Cuadrado et al. [297] have developed a new AD transgenic model combining the expression of hAPP and hTau proteins in wild type and Nrf2 knock-out mice. In this model, DMF reduced chronic neuroinflammation, augmented autophagy-related genes, and more importantly, recovered memory function in an Nrf2 activation-dependent mode. Thus, it was demonstrated that Nrf2 activation by DMF reduces inflammation and autophagy failure triggered by hAPP and hTau expression.

DMF has also been evaluated in several PD in vivo models reproducing the main pathological hallmarks of the human synucleinopathy [298], where DMF administration reduced the loss of nigrostriatal dopaminergic neurons by decreasing the neuroinflammatory status. It reduced microglia response to $\alpha$-synuclein, shifting it to an anti-inflammatory phenotype. Regarding the proteostasis system, DMF increased p62 protein levels and the LC3-II form, reducing autophagy vesicles. More importantly, DMF reversed motor deficit in $\alpha$-synuclein-expressing mice in a Nrf2-dependent manner.

Considering ALS, we have previously described the implication of OS, neuroinflammation, and proteostasis in this disease. DMF related Nrf2 induction has been associated with an anti-inflammatory response [299] in autoimmune diseases. As such, DMF has demonstrated the capacity to induce the activity of natural killer cells to target dendritic cells $(2,48)$. Furthermore, DMF induces the anti-inflammatory phenotype, augmenting the production of IL-10, a cytokine that induces the differentiation of CD4+ T cells to a suppressive Treg subtype $(2,24)$. Regulatory T cells are considered a key factor to regulate ALS progression as there is a close correlation between its advance and Treg levels [300]. Thus, the immunosuppression capacity of Tregs is critical to reducing disease progression, as demonstrated by the autologous infusion of normal suppressive function Tregs that slowed ALS progression in patients [301]. Interestingly, DMF has demonstrated effective improvement of Treg levels in patients [302] augmenting the ratio of anti-inflammatory Tcell populations [303], showing a strong reduction of pro-inflammatory CD4+ INF $\gamma+$ and CD8 + INF $\gamma+$ cells. Based on observations, Vucic et al. are developing the Phase II clinical trial (TEALS Study) to evaluate the efficacy and safety of DMF in ALS patients [304].

\section{Limitations and Future Perspective of the Antioxidant Therapy}

OS is considered an important component in the development of NDDs. Thus, it has been used as a target in many clinical trials towards different OS-associated diseases, including AD, PD, and ALS, among others. However, to date, none of them has been demonstrated to be effective for the treatment of these diseases. Recently, a novel antioxidant based on spin trapping was tested, compound NXY-059, that initially showed encouraging results, but finally, it failed to demonstrate efficacy [305]. Similarly, many other well-characterized antioxidants showed disappointing clinical results, such as tirilazad [306], ebselen [307], edavarone [308], and others, a phenomenon that has been called the "antioxidant paradox" [309].

Clinical failure of antioxidants has been attributed to several reasons [310]. One reason is the poor pharmacokinetic and pharmacodynamics of the tested compounds; usually, antioxidant drugs are highly polar molecules with high molecular weights that complicate their absorption. Furthermore, 
these compounds are usually characterized by a quick metabolism; thus, even if they reach the bloodstream, they are quickly metabolized and eliminated, an event that explains their poor distribution and low bioavailability. These properties also complicate the crossing of the different barriers, especially the $\mathrm{BBB}$, explaining part of the failure of these types of compounds in NDDs.

Another possible reason is the time and stage of administration. OS might be related to the initial stages of the disease; however, in later stages, there are many other pathological pathways involved in the advance of a particular disease. Thus, the application of antioxidant compounds might reduce the OS status without any activity in other pathological processes. In the particular case of NDDs, a general consensus is that the pathological process might start 10-15 years before the manifestation of the first symptoms; therefore, interventions at later stages might not be efficacious.

An important possibility that explains antioxidants' failure is the poor translation between animal models of NDDs and human patients. Laboratory animals selected are usually young, healthy, and homogeneous; however, patients are usually aged persons with a high number of comorbidities and are highly diverse. These, with other potential conditions, have demonstrated that, in general, animal models of NDDs do not simulate the real disease.

Another theory indicates that supplementation with antioxidants affects the natural redox equilibrium between pro-oxidant and antioxidant species, further increasing the redox homeostasis failure in NDDs [311]. Thus, the application of antioxidants might induce a reduction of the natural antioxidant response, increasing oxidative damage when antioxidants reduce their concentrations or bioavailability [312]. Therefore, the application of high concentrations of antioxidants might have a non-expected detrimental effect. This theory might be of particular importance in the failure of long-term antioxidants treatment of chronic NDDs.

Finally, another possibility is the poor mechanistic understanding of the antioxidant effect exerted by a particular antioxidant compound. For example, in some cases, molecules such as GSH can act via post-translational modifications to mediate protective effects; however, those protecting effects can be confused with an antioxidant effect. Thus, targeting free radicals with scavengers might not be the best antioxidant approach, and targeting the pathways that regulate their concentration can probably be a more efficacious approach. In this line, the use of the Nrf2-ARE pathway might suggest an important target to be combined with other pharmacological activities in a single molecule, an approach known as the "multitarget" drug development for NDDs.

\section{Conclusions}

NDDs are among the most complex diseases, and the initial causes remain elusive. Considering the physiopathology of these diseases, there are a plethora of common pathological mechanisms involved in onset and development, such as the apparition of aberrant protein aggregates, oxidative damage, metal ions dyshomeostasis, abnormal neuroinflammatory response, and extensive neuronal death. The existence of common pathological pathways in different NDDs points to this hypothesis in which common dysregulated processes cause initial damage over time and, after crossing the no-return-point, the formation of aberrant protein aggregates contributes to the exponential increase of damage, accelerating the advancement of the disease. This hypothesis agrees with the current consensus that the onset of NDDs could occur almost twenty years before the first clinical symptoms appear. In addition, the involvement of different brain systems might be related to an increased susceptibility of a particular subset of neurons due to still debated causes.

In this review, we highlight only a small piece of the vast complexity of the pathological network underlying NDDs like AD, PD, and ALS. The existence of low grade and chronic dysregulation in several key systems for cellular survival is increasingly recognized as a potential event occurring at the very early stages of the disease. More importantly, we have pointed to a few of the multitude of interconnected pathways between oxidative stress, neuroinflammation, and proteostasis, indicating the existence of a vast number of feedback loops that augment and accelerate the damage in each particular disease. However, many questions remain unsolved and, in our opinion, the most important 
question to solve is in which cases this low grade and chronic dysregulation becomes pathologic and how to diagnose it.

Considering drug development programs, the design of novel and real disease-modifying drugs should be driven based on the existence of these highly interconnected pathways. Considering the evidence described in this review, we believe that there are several systems that must be taken into consideration. In particular, the key role of damaged mitochondria, the failure of mitochondrial ETC complexes in different NDDs, and the presence of high levels of oxidized products in postmortem brains of NDDs patients indicate that oxidative stress might be an early event in NDDs. In addition, it has been widely demonstrated that oxidative stress damage induces neuroinflammation and both have intensive crosstalk to finally induce a highly toxic environment for neurons. Moreover, both pathological pathways are closely interconnected to the proteostasis system, in many cases, to inhibit its activity or damage its components to create the "perfect storm" that might be the driving force during the decades before the apparition of the first clinical sign. Thus, novel drugs or treatment combinations targeting all three pathological pathways, and, even more important, the crosstalk between them, might be the path to finding an effective treatment for NDDs.

Author Contributions: Conceptualization, P.M. and R.L.; writing—original draft preparation, P.M. and R.L.; writing-review and editing, P.M. and R.L.; All authors have read and agreed to the published version of the manuscript.

Funding: This research was funded by grants from IS Carlos III co-financed by the European Regional Development's funds (FEDER), Programa Miguel Servet II (CP16/00014) and research project (grant PI17/01700) to RL; Comunidad Autónoma de Madrid (grant B2017/BMD-3827) to RL.

Acknowledgments: P.M. thanks MECD for FPU fellowship (13/03737). We would also like to thank "Fundación Teófilo Hernando" for its continued support.

Conflicts of Interest: The authors declare no conflict of interest.

\section{References}

1. Fu, H.; Hardy, J.; Duff, K.E. Selective vulnerability in neurodegenerative diseases. Nat. Neurosci. 2018, 21, 1350-1358. [CrossRef]

2. Li, J.; Li, W.; Jiang, Z.G.; Ghanbari, H.A. Oxidative stress and neurodegenerative disorders. Int. J. Mol. Sci. 2013, 14, 24438-24475. [CrossRef]

3. Guzman-Martinez, L.; Maccioni, R.B.; Andrade, V.; Navarrete, L.P.; Pastor, M.G.; Ramos-Escobar, N. Neuroinflammation as a Common Feature of Neurodegenerative Disorders. Front. Pharmacol. 2019, 10, 1008. [CrossRef] [PubMed]

4. Sweeney, P.; Park, H.; Baumann, M.; Dunlop, J.; Frydman, J.; Kopito, R.; McCampbell, A.; Leblanc, G.; Venkateswaran, A.; Nurmi, A.; et al. Protein misfolding in neurodegenerative diseases: Implications and strategies. Transl. Neurodegener. 2017, 6, 6. [CrossRef] [PubMed]

5. Goate, A.; Chartier-Harlin, M.C.; Mullan, M.; Brown, J.; Crawford, F.; Fidani, L.; Giuffra, L.; Haynes, A.; Irving, N.; James, L.; et al. Segregation of a missense mutation in the amyloid precursor protein gene with familial Alzheimer's disease. Nature 1991, 349, 704-706. [CrossRef] [PubMed]

6. Brown, R.C.; Lockwood, A.H.; Sonawane, B.R. Neurodegenerative diseases: An overview of environmental risk factors. Environ. Health Perspect. 2005, 113, 1250-1256. [CrossRef] [PubMed]

7. Chen, X.; Guo, C.; Kong, J. Oxidative stress in neurodegenerative diseases. Neural. Regen. Res. 2012, 7, 376-385. [CrossRef]

8. Kim, G.H.; Kim, J.E.; Rhie, S.J; Yoon, S. The Role of Oxidative Stress in Neurodegenerative Diseases. Exp. Neurobiol. 2015, 24, 325-340. [CrossRef]

9. Thannickal, V.J.; Fanburg, B.L. Reactive oxygen species in cell signaling. Am. J. Physiol. Lung Cell Mol. Physiol. 2000, 279, L1005-L1028. [CrossRef]

10. Halliwell, B. Free Radicals and Other Reactive Species in Disease. eLS 2015. [CrossRef]

11. Pham-Huy, L.A.; He, H.; Pham-Huy, C. Free radicals, antioxidants in disease and health. Int. J. Biomed. Sci. 2008, 4, 89-96. [PubMed] 
12. Droge, W. Free radicals in the physiological control of cell function. Physiol. Rev. 2002, 82, 47-95. [CrossRef] [PubMed]

13. Sies, H.; Jones, D.P. Reactive oxygen species (ROS) as pleiotropic physiological signalling agents. Nat. Rev. Mol. Cell Biol. 2020, 10, 1-21. [CrossRef]

14. Murphy, M.P. How mitochondria produce reactive oxygen species. Biochem. J. 2009, 417, 1-13. [CrossRef] [PubMed]

15. Bedard, K.; Krause, K.H. The NOX family of ROS-generating NADPH oxidases: Physiology and pathophysiology. Physiol. Rev. 2007, 87, 245-313. [CrossRef]

16. Finkel, T.; Holbrook, N.J. Oxidants, oxidative stress and the biology of ageing. Nature 2000, 408, $239-247$. [CrossRef]

17. Boveris, A.; Chance, B. The mitochondrial generation of hydrogen peroxide. General properties and effect of hyperbaric oxygen. Biochem. J. 1973, 134, 707-716. [CrossRef]

18. De Duve, C.; Baudhuin, P. Peroxisomes (microbodies and related particles). Physiol. Rev. 1966, 46, $323-357$. [CrossRef]

19. Zangar, R.C.; Davydov, D.R.; Verma, S. Mechanisms that regulate production of reactive oxygen species by cytochrome P450. Toxicol. Appl. Pharmacol. 2004, 199, 316-331. [CrossRef]

20. Edmondson, D.E. Hydrogen peroxide produced by mitochondrial monoamine oxidase catalysis: Biological implications. Curr. Pharm. Des. 2014, 20, 155-160. [CrossRef]

21. Gu, Y.; Xu, Y.; Law, B.; Qian, S.Y. The first characterization of free radicals formed from cellular COX-catalyzed peroxidation. Free Radic. Biol. Med. 2013, 57, 49-60. [CrossRef] [PubMed]

22. Czapski, G.A.; Czubowicz, K.; Strosznajder, J.B.; Strosznajder, R.P. The Lipoxygenases: Their Regulation and Implication in Alzheimer's Disease. Neurochem. Res. 2016, 41, 243-257. [CrossRef] [PubMed]

23. Phaniendra, A.; Jestadi, D.B.; Periyasamy, L. Free radicals: Properties, sources, targets, and their implication in various diseases. Indian J. Clin. Biochem. 2015, 30, 11-26. [CrossRef] [PubMed]

24. Valko, M.; Leibfritz, D.; Moncol, J.; Cronin, M.T.; Mazur, M.; Telser, J. Free radicals and antioxidants in normal physiological functions and human disease. Int. J. Biochem. Cell Biol. 2007, 39, 44-84. [CrossRef]

25. Lambeth, J.D. NOX enzymes and the biology of reactive oxygen. Nat. Rev. Immunol. 2004, 4, 181-189. [CrossRef]

26. Infanger, D.W.; Sharma, R.V.; Davisson, R.L. NADPH oxidases of the brain: Distribution, regulation, and function. Antioxid. Redox Signal. 2006, 8, 1583-1596. [CrossRef]

27. Kuppusamy, P.; Zweier, J.L. Characterization of free radical generation by xanthine oxidase. Evidence for hydroxyl radical generation. J. Biol. Chem. 1989, 264, 9880-9884.

28. Turrens, J.F. Mitochondrial formation of reactive oxygen species. J. Physiol. 2003, 552, 335-344. [CrossRef]

29. Halliwell, B. Oxidative stress and neurodegeneration: Where are we now? J. Neurochem. 2006, 97, 1634-1658. [CrossRef]

30. Iles, K.E.; Forman, H.J. Macrophage signaling and respiratory burst. Immunol. Res. 2002, 26, 95-105. [CrossRef]

31. Babior, B.M.; Kipnes, R.S.; Curnutte, J.T. Biological defense mechanisms. The production by leukocytes of superoxide, a potential bactericidal agent. J. Clin. Investig. 1973, 52, 741-744. [CrossRef] [PubMed]

32. Buetler, T.M.; Krauskopf, A.; Ruegg, U.T. Role of superoxide as a signaling molecule. News Physiol. Sci. 2004, 19, 120-123. [CrossRef] [PubMed]

33. Fridovich, I. Superoxide anion radical $\left(\mathrm{O}_{2}-\right.$.), superoxide dismutases, and related matters. J. Biol. Chem. 1997, 272, 18515-18517. [CrossRef] [PubMed]

34. Macarthur, H.; Westfall, T.C.; Riley, D.P.; Misko, T.P.; Salvemini, D. Inactivation of catecholamines by superoxide gives new insights on the pathogenesis of septic shock. Proc. Natl. Acad. Sci. USA 2000, 97, 9753-9758. [CrossRef]

35. Muscoli, C.; Cuzzocrea, S.; Riley, D.P.; Zweier, J.L.; Thiemermann, C.; Wang, Z.Q.; Salvemini, D. On the selectivity of superoxide dismutase mimetics and its importance in pharmacological studies. Br. J. Pharmacol. 2003, 140, 445-460. [CrossRef]

36. Sies, H. Hydrogen peroxide as a central redox signaling molecule in physiological oxidative stress: Oxidative eustress. Redox Biol. 2017, 11, 613-619. [CrossRef] 
37. Rhee, S.G.; Yang, K.S.; Kang, S.W.; Woo, H.A.; Chang, T.S. Controlled elimination of intracellular $\mathrm{H}_{2} \mathrm{O}_{2}$ : Regulation of peroxiredoxin, catalase, and glutathione peroxidase via post-translational modification. Antioxid. Redox Signal. 2005, 7, 619-626. [CrossRef]

38. Lennicke, C.; Rahn, J.; Lichtenfels, R.; Wessjohann, L.A.; Seliger, B. Hydrogen peroxide - production, fate and role in redox signaling of tumor cells. Cell Commun. Signal. 2015, 13, 39. [CrossRef]

39. Biteau, B.; Labarre, J.; Toledano, M.B. ATP-dependent reduction of cysteine-sulphinic acid by S. cerevisiae sulphiredoxin. Nature 2003, 425, 980-984. [CrossRef]

40. Thomas, C.; Mackey, M.M.; Diaz, A.A.; Cox, D.P. Hydroxyl radical is produced via the Fenton reaction in submitochondrial particles under oxidative stress: Implications for diseases associated with iron accumulation. Redox Rep. 2009, 14, 102-108. [CrossRef]

41. Kehrer, J.P. The Haber-Weiss reaction and mechanisms of toxicity. Toxicology 2000, 149, 43-50. [CrossRef]

42. Schieber, M.; Chandel, N.S. ROS function in redox signaling and oxidative stress. Curr. Biol. 2014, 24, R453-R462. [CrossRef] [PubMed]

43. Moller, I.M.; Rogowska-Wrzesinska, A.; Rao, R.S. Protein carbonylation and metal-catalyzed protein oxidation in a cellular perspective. J. Proteom. 2011, 74, 2228-2242. [CrossRef] [PubMed]

44. Bergendi, L.; Benes, L.; Durackova, Z.; Ferencik, M. Chemistry, physiology and pathology of free radicals. Life Sci. 1999, 65, 1865-1874. [CrossRef]

45. Hess, D.T.; Matsumoto, A.; Kim, S.O.; Marshall, H.E.; Stamler, J.S. Protein S-nitrosylation: Purview and parameters. Nat. Rev. Mol. Cell Biol 2005, 6, 150-166. [CrossRef] [PubMed]

46. Beckman, J.S.; Koppenol, W.H. Nitric oxide, superoxide, and peroxynitrite: The good, the bad, and ugly. Am. J. Physiol. 1996, 271, C1424-C1437. [CrossRef]

47. Ischiropoulos, H.; Zhu, L.; Beckman, J.S. Peroxynitrite formation from macrophage-derived nitric oxide. Arch. Biochem. Biophys. 1992, 298, 446-451. [CrossRef]

48. Beckman, J.S.; Crow, J.P. Pathological implications of nitric oxide, superoxide and peroxynitrite formation. Biochem Soc. Trans. 1993, 21, 330-334. [CrossRef]

49. Carr, A.C.; McCall, M.R.; Frei, B. Oxidation of LDL by myeloperoxidase and reactive nitrogen species: Reaction pathways and antioxidant protection. Arterioscler. Thromb. Vasc. Biol. 2000, 20, 1716-1723. [CrossRef]

50. Douki, T.; Cadet, J. Peroxynitrite mediated oxidation of purine bases of nucleosides and isolated DNA. Free Radic. Res. 1996, 24, 369-380. [CrossRef]

51. Ischiropoulos, H.; al-Mehdi, A.B. Peroxynitrite-mediated oxidative protein modifications. FEBS Lett. 1995, 364, 279-282. [CrossRef]

52. Yamakura, F.; Taka, H.; Fujimura, T.; Murayama, K. Inactivation of human manganese-superoxide dismutase by peroxynitrite is caused by exclusive nitration of tyrosine 34 to 3-nitrotyrosine. J. Biol. Chem. 1998, 273, 14085-14089. [CrossRef] [PubMed]

53. Sauer, H.; Wartenberg, M.; Hescheler, J. Reactive Oxygen Species as Intracellular Messengers During Cell Growth and Differentiation. Cell. Physiol. Biochem. 2001, 11, 173-186. [CrossRef] [PubMed]

54. Day, R.M.; Suzuki, Y.J. Cell proliferation, reactive oxygen and cellular glutathione. Dose Response 2006, 3, 425-442. [CrossRef] [PubMed]

55. Jones, D.P. Radical-free biology of oxidative stress. Am. J. Physiol. Cell Physiol. 2008, 295, C849-C868. [CrossRef] [PubMed]

56. Finkel, T. Reactive oxygen species and signal transduction. IUBMB Life 2001, 52, 3-6. [CrossRef]

57. Salmeen, A.; Barford, D. Functions and mechanisms of redox regulation of cysteine-based phosphatases. Antioxid. Redox Signal. 2005, 7, 560-577. [CrossRef]

58. Groeger, G.; Quiney, C.; Cotter, T.G. Hydrogen peroxide as a cell-survival signaling molecule. Antioxid. Redox Signal. 2009, 11, 2655-2671. [CrossRef]

59. Shaulian, E.; Karin, M. AP-1 in cell proliferation and survival. Oncogene 2001, 20, 2390-2400. [CrossRef]

60. Semenza, G.L. HIF-1: Mediator of physiological and pathophysiological responses to hypoxia. J. Appl. Physiol. 2000, 88, 1474-1480. [CrossRef]

61. Itoh, K.; Chiba, T.; Takahashi, S.; Ishii, T.; Igarashi, K.; Katoh, Y.; Oyake, T.; Hayashi, N.; Satoh, K.; Hatayama, I.; et al. An Nrf2/small Maf heterodimer mediates the induction of phase II detoxifying enzyme genes through antioxidant response elements. Biochem. Biophys. Res. Commun. 1997, 236, 313-322. [CrossRef] [PubMed] 
62. Ma, Q. Role of nrf2 in oxidative stress and toxicity. Annu. Rev. Pharmacol. Toxicol. 2013, 53, 401-426. [CrossRef] [PubMed]

63. Kobayashi, A.; Kang, M.I.; Okawa, H.; Ohtsuji, M.; Zenke, Y.; Chiba, T.; Igarashi, K.; Yamamoto, M. Oxidative stress sensor Keap1 functions as an adaptor for Cul3-based E3 ligase to regulate proteasomal degradation of Nrf2. Mol. Cell Biol. 2004, 24, 7130-7139. [CrossRef] [PubMed]

64. Yamamoto, M.; Kensler, T.W.; Motohashi, H. The KEAP1-NRF2 System: A Thiol-Based Sensor-Effector Apparatus for Maintaining Redox Homeostasis. Physiol. Rev. 2018, 98, 1169-1203. [CrossRef] [PubMed]

65. Kobayashi, M.; Li, L.; Iwamoto, N.; Nakajima-Takagi, Y.; Kaneko, H.; Nakayama, Y.; Eguchi, M.; Wada, Y.; Kumagai, Y.; Yamamoto, M. The antioxidant defense system Keap1-Nrf2 comprises a multiple sensing mechanism for responding to a wide range of chemical compounds. Mol. Cell Biol. 2009, 29, 493-502. [CrossRef] [PubMed]

66. Wood, Z.A.; Schroder, E.; Robin Harris, J.; Poole, L.B. Structure, mechanism and regulation of peroxiredoxins. Trends Biochem. Sci. 2003, 28, 32-40. [CrossRef]

67. Dringen, R.; Gutterer, J.M.; Hirrlinger, J. Glutathione metabolism in brain metabolic interaction between astrocytes and neurons in the defense against reactive oxygen species. Eur. J. Biochem. 2000, 267, 4912-4916. [CrossRef]

68. Oeckinghaus, A.; Ghosh, S. The NF-kappaB family of transcription factors and its regulation. Cold Spring Harb. Perspect. Biol. 2009, 1, a000034. [CrossRef]

69. Pahl, H.L. Activators and target genes of Rel/NF-kappaB transcription factors. Oncogene 1999, 18, 6853-6866. [CrossRef]

70. Kabe, Y.; Ando, K.; Hirao, S.; Yoshida, M.; Handa, H. Redox regulation of NF-kappaB activation: Distinct redox regulation between the cytoplasm and the nucleus. Antioxid. Redox Signal. 2005, 7, 395-403. [CrossRef]

71. Guo, C.; Sun, L.; Chen, X.; Zhang, D. Oxidative stress, mitochondrial damage and neurodegenerative diseases. Neural Regen. Res. 2013, 8, 2003-2014. [CrossRef] [PubMed]

72. Fulda, S.; Gorman, A.M.; Hori, O.; Samali, A. Cellular stress responses: Cell survival and cell death. Int. J. Cell Biol. 2010, 2010, 214074. [CrossRef] [PubMed]

73. Frank, M.; Duvezin-Caubet, S.; Koob, S.; Occhipinti, A.; Jagasia, R.; Petcherski, A.; Ruonala, M.O.; Priault, M.; Salin, B.; Reichert, A.S. Mitophagy is triggered by mild oxidative stress in a mitochondrial fission dependent manner. Biochim. Biophys. Acta 2012, 1823, 2297-2310. [CrossRef] [PubMed]

74. Kowaltowski, A.J.; Castilho, R.F.; Vercesi, A.E. Mitochondrial permeability transition and oxidative stress. FEBS Lett. 2001, 495, 12-15. [CrossRef]

75. Masaldan, S.; Bush, A.I.; Devos, D.; Rolland, A.S.; Moreau, C. Striking while the iron is hot: Iron metabolism and ferroptosis in neurodegeneration. Free Radic. Biol. Med. 2019, 133, 221-233. [CrossRef]

76. Kalani, K.; Yan, S.F.; Yan, S.S. Mitochondrial permeability transition pore: A potential drug target for neurodegeneration. Drug Discov. Today 2018, 23, 1983-1989. [CrossRef]

77. Lehner, C.; Gehwolf, R.; Tempfer, H.; Krizbai, I.; Hennig, B.; Bauer, H.C.; Bauer, H. Oxidative stress and blood-brain barrier dysfunction under particular consideration of matrix metalloproteinases. Antioxid. Redox Signal. 2011, 15, 1305-1323. [CrossRef]

78. Halliwell, B. Reactive oxygen species and the central nervous system. J. Neurochem. 1992, 59, $1609-1623$. [CrossRef]

79. Tang, B.L. Glucose, glycolysis, and neurodegenerative diseases. J. Cell Physiol. 2020. [CrossRef]

80. Butterfield, D.A.; Halliwell, B. Oxidative stress, dysfunctional glucose metabolism and Alzheimer disease. Nat. Rev. Neurosci. 2019, 20, 148-160. [CrossRef]

81. Spencer, J.P.; Jenner, P.; Daniel, S.E.; Lees, A.J.; Marsden, D.C.; Halliwell, B. Conjugates of catecholamines with cysteine and GSH in Parkinson's disease: Possible mechanisms of formation involving reactive oxygen species. J. Neurochem. 1998, 71, 2112-2122. [CrossRef] [PubMed]

82. Zecca, L.; Youdim, M.B.; Riederer, P.; Connor, J.R.; Crichton, R.R. Iron, brain ageing and neurodegenerative disorders. Nat. Rev. Neurosci. 2004, 5, 863-873. [CrossRef] [PubMed]

83. Mark, R.J.; Lovell, M.A.; Markesbery, W.R.; Uchida, K.; Mattson, M.P. A role for 4-hydroxynonenal, an aldehydic product of lipid peroxidation, in disruption of ion homeostasis and neuronal death induced by amyloid beta-peptide. J. Neurochem. 1997, 68, 255-264. [CrossRef] [PubMed] 
84. Choi, I.Y.; Lim, J.H.; Kim, C.; Song, H.Y.; Ju, C.; Kim, W.K. 4-hydroxy-2(E)-Nonenal facilitates NMDA-Induced Neurotoxicity via Triggering Mitochondrial Permeability Transition Pore Opening and Mitochondrial Calcium Overload. Exp. Neurobiol. 2013, 22, 200-207. [CrossRef]

85. Gil, L.; Siems, W.; Mazurek, B.; Gross, J.; Schroeder, P.; Voss, P.; Grune, T. Age-associated analysis of oxidative stress parameters in human plasma and erythrocytes. Free Radic. Res. 2006, 40, 495-505. [CrossRef]

86. Saxena, S.; Caroni, P. Selective neuronal vulnerability in neurodegenerative diseases: From stressor thresholds to degeneration. Neuron 2011, 71, 35-48. [CrossRef]

87. Wang, X.; Michaelis, E.K. Selective neuronal vulnerability to oxidative stress in the brain. Front. Aging Neurosci. 2010, 2, 12. [CrossRef]

88. Hyman, B.T.; Van Hoesen, G.W.; Damasio, A.R.; Barnes, C.L. Alzheimer's disease: Cell-specific pathology isolates the hippocampal formation. Science 1984, 225, 1168-1170. [CrossRef]

89. Stranahan, A.M.; Mattson, M.P. Selective vulnerability of neurons in layer II of the entorhinal cortex during aging and Alzheimer's disease. Neural Plast. 2010, 2010, 108190. [CrossRef]

90. Bondareff, W.; Mountjoy, C.Q.; Roth, M. Loss of neurons of origin of the adrenergic projection to cerebral cortex (nucleus locus ceruleus) in senile dementia. Neurology 1982, 32, 164-168. [CrossRef]

91. Whitehouse, P.J.; Price, D.L.; Struble, R.G.; Clark, A.W.; Coyle, J.T.; Delon, M.R. Alzheimer's disease and senile dementia: Loss of neurons in the basal forebrain. Science 1982, 215, 1237-1239. [CrossRef] [PubMed]

92. Dauer, W.; Przedborski, S. Parkinson's disease: Mechanisms and models. Neuron 2003, 39, 889-909. [CrossRef]

93. Rowland, L.P.; Shneider, N.A. Amyotrophic lateral sclerosis. N. Engl. J. Med. 2001, 344, 1688-1700. [CrossRef] [PubMed]

94. Hof, P.R.; Nimchinsky, E.A.; Celio, M.R.; Bouras, C.; Morrison, J.H. Calretinin-immunoreactive neocortical interneurons are unaffected in Alzheimer's disease. Neurosci. Lett. 1993, 152, 145-148. [CrossRef]

95. Yamada, T.; McGeer, P.L.; Baimbridge, K.G.; McGeer, E.G. Relative sparing in Parkinson's disease of substantia nigra dopamine neurons containing calbindin-D28K. Brain Res. 1990, 526, 303-307. [CrossRef]

96. Bolam, J.P.; Pissadaki, E.K. Living on the edge with too many mouths to feed: Why dopamine neurons die. Mov. Disord. 2012, 27, 1478-1483. [CrossRef]

97. Lee, H.G.; Ogawa, O.; Zhu, X.; O’Neill, M.J.; Petersen, R.B.; Castellani, R.J.; Ghanbari, H.; Perry, G.; Smith, M.A. Aberrant expression of metabotropic glutamate receptor 2 in the vulnerable neurons of Alzheimer's disease. Acta Neuropathol. 2004, 107, 365-371. [CrossRef]

98. Tomiyama, M.; Kimura, T.; Maeda, T.; Tanaka, H.; Furusawa, K.; Kurahashi, K.; Matsunaga, M. Expression of metabotropic glutamate receptor mRNAs in the human spinal cord: Implications for selective vulnerability of spinal motor neurons in amyotrophic lateral sclerosis. J. Neurol. Sci. 2001, 189, 65-69. [CrossRef]

99. Lovell, M.A.; Ehmann, W.D.; Mattson, M.P.; Markesbery, W.R. Elevated 4-hydroxynonenal in ventricular fluid in Alzheimer's disease. Neurobiol. Aging 1997, 18, 457-461. [CrossRef]

100. Rhein, V.; Song, X.; Wiesner, A.; Ittner, L.M.; Baysang, G.; Meier, F.; Ozmen, L.; Bluethmann, H.; Drose, S.; Brandt, U.; et al. Amyloid-beta and tau synergistically impair the oxidative phosphorylation system in triple transgenic Alzheimer's disease mice. Proc. Natl. Acad. Sci. USA 2009, 106, 20057-20062. [CrossRef]

101. Opazo, C.; Huang, X.; Cherny, R.A.; Moir, R.D.; Roher, A.E.; White, A.R.; Cappai, R.; Masters, C.L.; Tanzi, R.E.; Inestrosa, N.C.; et al. Metalloenzyme-like activity of Alzheimer's disease beta-amyloid. $\mathrm{Cu}$-dependent catalytic conversion of dopamine, cholesterol, and biological reducing agents to neurotoxic $\mathrm{H}_{2} \mathrm{O}_{2}$. J. Biol. Chem. 2002, 277, 40302-40308. [CrossRef] [PubMed]

102. Schapira, A.H. Mitochondria in the aetiology and pathogenesis of Parkinson's disease. Lancet Neurol. 2008, 7, 97-109. [CrossRef]

103. Blesa, J.; Trigo-Damas, I.; Quiroga-Varela, A.; Jackson-Lewis, V.R. Oxidative stress and Parkinson's disease. Front. Neuroanat. 2015, 9, 91. [CrossRef] [PubMed]

104. Hauser, D.N.; Hastings, T.G. Mitochondrial dysfunction and oxidative stress in Parkinson's disease and monogenic parkinsonism. Neurobiol. Dis. 2013, 51, 35-42. [CrossRef] [PubMed]

105. Hirsch, E.C.; Brandel, J.P.; Galle, P.; Javoy-Agid, F.; Agid, Y. Iron and aluminum increase in the substantia nigra of patients with Parkinson's disease: An X-ray microanalysis. J. Neurochem. 1991, 56, 446-451. [CrossRef] [PubMed]

106. Valentine, J.S.; Hart, P.J. Misfolded CuZnSOD and amyotrophic lateral sclerosis. Proc. Natl. Acad. Sci. USA 2003, 100, 3617-3622. [CrossRef] 
107. Li, Q.; Spencer, N.Y.; Pantazis, N.J.; Engelhardt, J.F. Alsin and SOD1(G93A) proteins regulate endosomal reactive oxygen species production by glial cells and proinflammatory pathways responsible for neurotoxicity. J. Biol. Chem. 2011, 286, 40151-40162. [CrossRef]

108. Ganguly, G.; Chakrabarti, S.; Chatterjee, U.; Saso, L. Proteinopathy, oxidative stress and mitochondrial dysfunction: Cross talk in Alzheimer's disease and Parkinson's disease. Drug Des. Dev. Ther. 2017, 11, 797-810. [CrossRef]

109. Levy, E.; El Banna, N.; Baille, D.; Heneman-Masurel, A.; Truchet, S.; Rezaei, H.; Huang, M.E.; Beringue, V.; Martin, D.; Vernis, L. Causative Links between Protein Aggregation and Oxidative Stress: A Review. Int. J. Mol. Sci. 2019, 20, 3896. [CrossRef]

110. Bergamini, E.; Cavallini, G.; Donati, A.; Gori, Z. The role of macroautophagy in the ageing process, anti-ageing intervention and age-associated diseases. Int. J. Biochem. Cell Biol. 2004, 36, 2392-2404. [CrossRef]

111. Cuervo, A.M.; Wong, E. Chaperone-mediated autophagy: Roles in disease and aging. Cell Res. 2014, 24, 92-104. [CrossRef] [PubMed]

112. Saez, I.; Vilchez, D. The Mechanistic Links Between Proteasome Activity, Aging and Age-related Diseases. Curr. Genom. 2014, 15, 38-51. [CrossRef] [PubMed]

113. Pajares, M.; Jimenez-Moreno, N.; Dias, I.H.K.; Debelec, B.; Vucetic, M.; Fladmark, K.E.; Basaga, H.; Ribaric, S.; Milisav, I.; Cuadrado, A. Redox control of protein degradation. Redox Biol. 2015, 6, 409-420. [CrossRef] [PubMed]

114. Cheignon, C.; Tomas, M.; Bonnefont-Rousselot, D.; Faller, P.; Hureau, C.; Collin, F. Oxidative stress and the amyloid beta peptide in Alzheimer's disease. Redox Biol. 2018, 14, 450-464. [CrossRef] [PubMed]

115. Devi, L.; Prabhu, B.M.; Galati, D.F.; Avadhani, N.G.; Anandatheerthavarada, H.K. Accumulation of amyloid precursor protein in the mitochondrial import channels of human Alzheimer's disease brain is associated with mitochondrial dysfunction. J. Neurosci. 2006, 26, 9057-9068. [CrossRef]

116. Grassi, D.; Howard, S.; Zhou, M.; Diaz-Perez, N.; Urban, N.T.; Guerrero-Given, D.; Kamasawa, N.; Volpicelli-Daley, L.A.; LoGrasso, P.; Lasmezas, C.I. Identification of a highly neurotoxic alpha-synuclein species inducing mitochondrial damage and mitophagy in Parkinson's disease. Proc. Natl. Acad. Sci. USA 2018, 115, E2634-E2643. [CrossRef]

117. Paillusson, S.; Stoica, R.; Gomez-Suaga, P.; Lau, D.H.W.; Mueller, S.; Miller, T.; Miller, C.C.J. There's Something Wrong with my MAM; the ER-Mitochondria Axis and Neurodegenerative Diseases. Trends Neurosci. 2016, 39, 146-157. [CrossRef]

118. Wang, S.; Kaufman, R.J. The impact of the unfolded protein response on human disease. J. Cell Biol. 2012, 197, 857-867. [CrossRef]

119. Bhandary, B.; Marahatta, A.; Kim, H.R.; Chae, H.J. An involvement of oxidative stress in endoplasmic reticulum stress and its associated diseases. Int. J. Mol. Sci. 2012, 14, 434-456. [CrossRef]

120. Doyle, K.M.; Kennedy, D.; Gorman, A.M.; Gupta, S.; Healy, S.J.; Samali, A. Unfolded proteins and endoplasmic reticulum stress in neurodegenerative disorders. J. Cell Mol. Med. 2011, 15, 2025-2039. [CrossRef]

121. Bartesaghi, S.; Radi, R. Fundamentals on the biochemistry of peroxynitrite and protein tyrosine nitration. Redox Biol. 2018, 14, 618-625. [CrossRef] [PubMed]

122. Dalle-Donne, I.; Giustarini, D.; Colombo, R.; Rossi, R.; Milzani, A. Protein carbonylation in human diseases. Trends Mol. Med. 2003, 9, 169-176. [CrossRef]

123. Weng, S.L.; Huang, K.Y.; Kaunang, F.J.; Huang, C.H.; Kao, H.J.; Chang, T.H.; Wang, H.Y.; Lu, J.J.; Lee, T.Y. Investigation and identification of protein carbonylation sites based on position-specific amino acid composition and physicochemical features. BMC Bioinform. 2017, 18, 66. [CrossRef] [PubMed]

124. Nystrom, T. Role of oxidative carbonylation in protein quality control and senescence. EMBO J. 2005, 24, 1311-1317. [CrossRef]

125. Hohn, A.; Weber, D.; Jung, T.; Ott, C.; Hugo, M.; Kochlik, B.; Kehm, R.; Konig, J.; Grune, T.; Castro, J.P. Happily (n)ever after: Aging in the context of oxidative stress, proteostasis loss and cellular senescence. Redox Biol. 2017, 11, 482-501. [CrossRef]

126. Grune, T.; Jung, T.; Merker, K.; Davies, K.J. Decreased proteolysis caused by protein aggregates, inclusion bodies, plaques, lipofuscin, ceroid, and 'aggresomes' during oxidative stress, aging, and disease. Int. J. Biochem. Cell Biol. 2004, 36, 2519-2530. [CrossRef]

127. Reinheckel, T.; Sitte, N.; Ullrich, O.; Kuckelkorn, U.; Davies, K.J.; Grune, T. Comparative resistance of the $20 \mathrm{~S}$ and $26 \mathrm{~S}$ proteasome to oxidative stress. Biochem. J. 1998, 335, 637-642. [CrossRef] 
128. Jahngen-Hodge, J.; Obin, M.S.; Gong, X.; Shang, F.; Nowell, T.R., Jr.; Gong, J.; Abasi, H.; Blumberg, J.; Taylor, A. Regulation of ubiquitin-conjugating enzymes by glutathione following oxidative stress. J. Biol. Chem. 1997, 272, 28218-28226. [CrossRef]

129. Yao, D.; Gu, Z.; Nakamura, T.; Shi, Z.Q.; Ma, Y.; Gaston, B.; Palmer, L.A.; Rockenstein, E.M.; Zhang, Z.; Masliah, E.; et al. Nitrosative stress linked to sporadic Parkinson's disease: S-nitrosylation of parkin regulates its E3 ubiquitin ligase activity. Proc. Natl. Acad. Sci. USA 2004, 101, 10810-10814. [CrossRef]

130. Bonet-Costa, V.; Pomatto, L.C.; Davies, K.J. The Proteasome and Oxidative Stress in Alzheimer's Disease. Antioxid. Redox Signal. 2016, 25, 886-901. [CrossRef]

131. Bentea, E.; Verbruggen, L.; Massie, A. The Proteasome Inhibition Model of Parkinson's Disease. J. Parkinsons Dis. 2017, 7, 31-63. [CrossRef] [PubMed]

132. Nah, J.; Yuan, J.; Jung, Y.K. Autophagy in neurodegenerative diseases: From mechanism to therapeutic approach. Mol. Cells 2015, 38, 381-389. [CrossRef] [PubMed]

133. Yue, Z.; Friedman, L.; Komatsu, M.; Tanaka, K. The cellular pathways of neuronal autophagy and their implication in neurodegenerative diseases. Biochim. Biophys. Acta 2009, 1793, 1496-1507. [CrossRef] [PubMed]

134. Scherz-Shouval, R.; Shvets, E.; Fass, E.; Shorer, H.; Gil, L.; Elazar, Z. Reactive oxygen species are essential for autophagy and specifically regulate the activity of Atg4. EMBO J. 2007, 26, 1749-1760. [CrossRef]

135. Carroll, B.; Otten, E.G.; Manni, D.; Stefanatos, R.; Menzies, F.M.; Smith, G.R.; Jurk, D.; Kenneth, N.; Wilkinson, S.; Passos, J.F.; et al. Oxidation of SQSTM1/p62 mediates the link between redox state and protein homeostasis. Nat. Commun. 2018, 9, 256. [CrossRef]

136. Kiffin, R.; Christian, C.; Knecht, E.; Cuervo, A.M. Activation of chaperone-mediated autophagy during oxidative stress. Mol. Biol. Cell 2004, 15, 4829-4840. [CrossRef]

137. Kiffin, R.; Bandyopadhyay, U.; Cuervo, A.M. Oxidative stress and autophagy. Antioxid. Redox Signal. 2006, 8, 152-162. [CrossRef]

138. Hohn, A.; Grune, T. Lipofuscin: Formation, effects and role of macroautophagy. Redox Biol. 2013, 1, $140-144$. [CrossRef]

139. Sedlackova, L.; Kelly, G.; Korolchuk, V.I. The pROS of Autophagy in Neuronal Health. J. Mol. Biol. 2020, 432, 2546-2559. [CrossRef]

140. Wyss-Coray, T.; Mucke, L. Inflammation in neurodegenerative disease-A double-edged sword. Neuron 2002, 35, 419-432. [CrossRef]

141. Hickey, W.F. Basic principles of immunological surveillance of the normal central nervous system. Glia 2001, 36, 118-124. [CrossRef] [PubMed]

142. Saijo, K.; Glass, C.K. Microglial cell origin and phenotypes in health and disease. Nat. Rev. Immunol. 2011, 11, 775-787. [CrossRef] [PubMed]

143. Gonzalez, H.; Elgueta, D.; Montoya, A.; Pacheco, R. Neuroimmune regulation of microglial activity involved in neuroinflammation and neurodegenerative diseases. J. Neuroimmunol. 2014, 274, 1-13. [CrossRef] [PubMed]

144. Cherry, J.D.; Olschowka, J.A.; O'Banion, M.K. Neuroinflammation and M2 microglia: The good, the bad, and the inflamed. J. Neuroinflamm. 2014, 11, 98. [CrossRef] [PubMed]

145. Sofroniew, M.V.; Vinters, H.V. Astrocytes: Biology and pathology. Acta Neuropathol. 2010, 119, 7-35. [CrossRef]

146. Pekny, M.; Wilhelmsson, U.; Pekna, M. The dual role of astrocyte activation and reactive gliosis. Neurosci. Lett. 2014, 565, 30-38. [CrossRef]

147. Chung, I.Y.; Benveniste, E.N. Tumor necrosis factor-alpha production by astrocytes. Induction by lipopolysaccharide, IFN-gamma, and IL-1 beta. J. Immunol. 1990, 144, 2999-3007.

148. Damier, P.; Hirsch, E.C.; Zhang, P.; Agid, Y.; Javoy-Agid, F. Glutathione peroxidase, glial cells and Parkinson's disease. Neuroscience 1993, 52, 1-6. [CrossRef]

149. Mittal, M.; Siddiqui, M.R.; Tran, K.; Reddy, S.P.; Malik, A.B. Reactive oxygen species in inflammation and tissue injury. Antioxid. Redox Signal. 2014, 20, 1126-1167. [CrossRef]

150. Naik, E.; Dixit, V.M. Mitochondrial reactive oxygen species drive proinflammatory cytokine production. J. Exp. Med. 2011, 208, 417-420. [CrossRef] 
151. West, A.P.; Brodsky, I.E.; Rahner, C.; Woo, D.K.; Erdjument-Bromage, H.; Tempst, P.; Walsh, M.C.; Choi, Y.; Shadel, G.S.; Ghosh, S. TLR signalling augments macrophage bactericidal activity through mitochondrial ROS. Nature 2011, 472, 476-480. [CrossRef] [PubMed]

152. Martinon, F. Signaling by ROS drives inflammasome activation. Eur. J. Immunol. 2010, 40, 616-619. [CrossRef] [PubMed]

153. Roh, J.S.; Sohn, D.H. Damage-Associated Molecular Patterns in Inflammatory Diseases. Immune Netw. 2018, 18, e27. [CrossRef] [PubMed]

154. Marinelli, S.; Basilico, B.; Marrone, M.C.; Ragozzino, D. Microglia-neuron crosstalk: Signaling mechanism and control of synaptic transmission. Semin. Cell Dev. Biol. 2019, 94, 138-151. [CrossRef] [PubMed]

155. Limatola, C.; Ransohoff, R.M. Modulating neurotoxicity through CX3CL1/CX3CR1 signaling. Front. Cell Neurosci. 2014, 8, 229. [CrossRef]

156. Shi, Q.; Chowdhury, S.; Ma, R.; Le, K.X.; Hong, S.; Caldarone, B.J.; Stevens, B.; Lemere, C.A. Complement C3 deficiency protects against neurodegeneration in aged plaque-rich APP/PS1 mice. Sci. Transl. Med. 2017, 9. [CrossRef]

157. De Lella Ezcurra, A.L.; Chertoff, M.; Ferrari, C.; Graciarena, M.; Pitossi, F. Chronic expression of low levels of tumor necrosis factor-alpha in the substantia nigra elicits progressive neurodegeneration, delayed motor symptoms and microglia/macrophage activation. Neurobiol. Dis. 2010, 37, 630-640. [CrossRef]

158. Norden, D.M.; Godbout, J.P. Review: Microglia of the aged brain: Primed to be activated and resistant to regulation. Neuropathol. Appl. Neurobiol. 2013, 39, 19-34. [CrossRef]

159. Perry, V.H.; Holmes, C. Microglial priming in neurodegenerative disease. Nat. Rev. Neurol. 2014, 10, $217-224$. [CrossRef]

160. Rojo, A.I.; McBean, G.; Cindric, M.; Egea, J.; Lopez, M.G.; Rada, P.; Zarkovic, N.; Cuadrado, A. Redox control of microglial function: Molecular mechanisms and functional significance. Antioxid. Redox Signal. 2014, 21, 1766-1801. [CrossRef]

161. Hook, S.; Roberts, K.; Kumita, J.; Yerbury, J. The Interplay of Protein Aggregates, Microglia and Neuroinflammation in Neurodegenerative Disease. In Microglia: Physiology, Regulation and Health Implications; Nova Science Publishers: New York, NY, USA, 2015; pp. 157-204.

162. Zhang, K.; Kaufman, R.J. From endoplasmic-reticulum stress to the inflammatory response. Nature 2008, 454, 455-462. [CrossRef] [PubMed]

163. Su, P.; Zhang, J.; Wang, D.; Zhao, F.; Cao, Z.; Aschner, M.; Luo, W. The role of autophagy in modulation of neuroinflammation in microglia. Neuroscience 2016, 319, 155-167. [CrossRef] [PubMed]

164. Francois, A.; Terro, F.; Janet, T.; Rioux Bilan, A.; Paccalin, M.; Page, G. Involvement of interleukin-1beta in the autophagic process of microglia: Relevance to Alzheimer's disease. J. Neuroinflamm. 2013, 10, 151. [CrossRef] [PubMed]

165. Mattson, M.P. Pathways towards and away from Alzheimer's disease. Nature 2004, 430, 631-639. [CrossRef] [PubMed]

166. Talwar, P.; Sinha, J.; Grover, S.; Rawat, C.; Kushwaha, S.; Agarwal, R.; Taneja, V.; Kukreti, R. Dissecting Complex and Multifactorial Nature of Alzheimer's Disease Pathogenesis: A Clinical, Genomic, and Systems Biology Perspective. Mol. Neurobiol. 2016, 53, 4833-4864. [CrossRef] [PubMed]

167. Swerdlow, R.H. Mitochondria and Mitochondrial Cascades in Alzheimer's Disease. J. Alzheimers Dis. 2018, 62, 1403-1416. [CrossRef]

168. Cioffi, F.; Adam, R.H.I.; Broersen, K. Molecular Mechanisms and Genetics of Oxidative Stress in Alzheimer's Disease. J. Alzheimers Dis. 2019, 72, 981-1017. [CrossRef]

169. Heppner, F.L.; Ransohoff, R.M.; Becher, B. Immune attack: The role of inflammation in Alzheimer disease. Nat. Rev. Neurosci. 2015, 16, 358-372. [CrossRef]

170. Di Meco, A.; Curtis, M.E.; Lauretti, E.; Pratico, D. Autophagy Dysfunction in Alzheimer's Disease: Mechanistic Insights and New Therapeutic Opportunities. Biol. Psychiatry 2020, 87, 797-807. [CrossRef]

171. Martinez-Vicente, M.; Cuervo, A.M. Autophagy and neurodegeneration: When the cleaning crew goes on strike. Lancet Neurol. 2007, 6, 352-361. [CrossRef]

172. Grimm, A.; Eckert, A. Brain aging and neurodegeneration: From a mitochondrial point of view. J. Neurochem. 2017, 143, 418-431. [CrossRef] [PubMed]

173. Patten, D.A.; Germain, M.; Kelly, M.A.; Slack, R.S. Reactive oxygen species: Stuck in the middle of neurodegeneration. J. Alzheimer Dis. JAD 2010, 20, S357-S367. [CrossRef] [PubMed] 
174. Moreira, P.I.; Carvalho, C.; Zhu, X.; Smith, M.A.; Perry, G. Mitochondrial dysfunction is a trigger of Alzheimer's disease pathophysiology. Biochim. Biophys. Acta 2010, 1802, 2-10. [CrossRef] [PubMed]

175. Caspersen, C.; Wang, N.; Yao, J.; Sosunov, A.; Chen, X.; Lustbader, J.W.; Xu, H.W.; Stern, D.; McKhann, G.; Yan, S.D. Mitochondrial Abeta: A potential focal point for neuronal metabolic dysfunction in Alzheimer's disease. FASEB J. 2005, 19, 2040-2041. [CrossRef] [PubMed]

176. Canevari, L.; Clark, J.B.; Bates, T.E. beta-Amyloid fragment 25-35 selectively decreases complex IV activity in isolated mitochondria. FEBS Lett. 1999, 457, 131-134. [CrossRef]

177. Owen, J.B.; Sultana, R.; Aluise, C.D.; Erickson, M.A.; Price, T.O.; Bu, G.; Banks, W.A.; Butterfield, D.A. Oxidative modification to LDL receptor-related protein 1 in hippocampus from subjects with Alzheimer disease: Implications for Abeta accumulation in AD brain. Free Radic. Biol. Med. 2010, 49, 1798-1803. [CrossRef]

178. Lloret, A.; Badia, M.C.; Giraldo, E.; Ermak, G.; Alonso, M.D.; Pallardo, F.V.; Davies, K.J.; Vina, J. Amyloid-beta toxicity and tau hyperphosphorylation are linked via RCAN1 in Alzheimer's disease. J. Alzheimers Dis. 2011, 27, 701-709. [CrossRef]

179. Leroy, K.; Yilmaz, Z.; Brion, J.P. Increased level of active GSK-3beta in Alzheimer's disease and accumulation in argyrophilic grains and in neurones at different stages of neurofibrillary degeneration. Neuropathol. Appl. Neurobiol. 2007, 33, 43-55. [CrossRef]

180. Schweers, O.; Mandelkow, E.M.; Biernat, J.; Mandelkow, E. Oxidation of cysteine-322 in the repeat domain of microtubule-associated protein tau controls the in vitro assembly of paired helical filaments. Proc. Natl. Acad. Sci. USA 1995, 92, 8463-8467. [CrossRef]

181. Vana, L.; Kanaan, N.M.; Hakala, K.; Weintraub, S.T.; Binder, L.I. Peroxynitrite-induced nitrative and oxidative modifications alter tau filament formation. Biochemistry 2011, 50, 1203-1212. [CrossRef]

182. Hohman, T.J.; Koran, M.E.; Thornton-Wells, T.A.; Alzheimer's Neuroimaging, I. Interactions between GSK3beta and amyloid genes explain variance in amyloid burden. Neurobiol. Aging 2014, 35, 460-465. [CrossRef] [PubMed]

183. Hooper, C.; Killick, R.; Lovestone, S. The GSK3 hypothesis of Alzheimer's disease. J. Neurochem. 2008, 104, 1433-1439. [CrossRef] [PubMed]

184. Rada, P.; Rojo, A.I.; Chowdhry, S.; McMahon, M.; Hayes, J.D.; Cuadrado, A. SCF/\{beta\}-TrCP promotes glycogen synthase kinase 3-dependent degradation of the Nrf2 transcription factor in a Keap1-independent manner. Mol. Cell Biol. 2011, 31, 1121-1133. [CrossRef] [PubMed]

185. Swardfager, W.; Lanctot, K.; Rothenburg, L.; Wong, A.; Cappell, J.; Herrmann, N. A meta-analysis of cytokines in Alzheimer's disease. Biol. Psychiatry 2010, 68, 930-941. [CrossRef]

186. Blum-Degen, D.; Muller, T.; Kuhn, W.; Gerlach, M.; Przuntek, H.; Riederer, P. Interleukin-1 beta and interleukin-6 are elevated in the cerebrospinal fluid of Alzheimer's and de novo Parkinson's disease patients. Neurosci. Lett. 1995, 202, 17-20. [CrossRef]

187. Akama, K.T.; Van Eldik, L.J. Beta-amyloid stimulation of inducible nitric-oxide synthase in astrocytes is interleukin-1beta- and tumor necrosis factor-alpha (TNFalpha)-dependent, and involves a TNFalpha receptor-associated factor- and NFkappaB-inducing kinase-dependent signaling mechanism. J. Biol. Chem. 2000, 275, 7918-7924. [CrossRef]

188. Kummer, M.P.; Hermes, M.; Delekarte, A.; Hammerschmidt, T.; Kumar, S.; Terwel, D.; Walter, J.; Pape, H.C.; Konig, S.; Roeber, S.; et al. Nitration of tyrosine 10 critically enhances amyloid beta aggregation and plaque formation. Neuron 2011, 71, 833-844. [CrossRef]

189. Hensley, K.; Maidt, M.L.; Yu, Z.; Sang, H.; Markesbery, W.R.; Floyd, R.A. Electrochemical analysis of protein nitrotyrosine and dityrosine in the Alzheimer brain indicates region-specific accumulation. J. Neurosci. 1998, 18, 8126-8132. [CrossRef]

190. Stewart, C.R.; Stuart, L.M.; Wilkinson, K.; van Gils, J.M.; Deng, J.; Halle, A.; Rayner, K.J.; Boyer, L.; Zhong, R.; Frazier, W.A.; et al. CD36 ligands promote sterile inflammation through assembly of a Toll-like receptor 4 and 6 heterodimer. Nat. Immunol. 2010, 11, 155-161. [CrossRef]

191. Sheedy, F.J.; Grebe, A.; Rayner, K.J.; Kalantari, P.; Ramkhelawon, B.; Carpenter, S.B.; Becker, C.E.; Ediriweera, H.N.; Mullick, A.E.; Golenbock, D.T.; et al. CD36 coordinates NLRP3 inflammasome activation by facilitating intracellular nucleation of soluble ligands into particulate ligands in sterile inflammation. Nat. Immunol. 2013, 14, 812-820. [CrossRef] 
192. Kitazawa, M.; Cheng, D.; Tsukamoto, M.R.; Koike, M.A.; Wes, P.D.; Vasilevko, V.; Cribbs, D.H.; LaFerla, F.M. Blocking IL-1 signaling rescues cognition, attenuates tau pathology, and restores neuronal beta-catenin pathway function in an Alzheimer's disease model. J. Immunol. 2011, 187, 6539-6549. [CrossRef] [PubMed]

193. Carroll, B.; Hewitt, G.; Korolchuk, V.I. Autophagy and ageing: Implications for age-related neurodegenerative diseases. Essays Biochem. 2013, 55, 119-131. [CrossRef] [PubMed]

194. Nixon, R.A. The role of autophagy in neurodegenerative disease. Nat. Med. 2013, 19, 983-997. [CrossRef] [PubMed]

195. Tseng, B.P.; Green, K.N.; Chan, J.L.; Blurton-Jones, M.; LaFerla, F.M. Abeta inhibits the proteasome and enhances amyloid and tau accumulation. Neurobiol. Aging 2008, 29, 1607-1618. [CrossRef] [PubMed]

196. Di Domenico, F.; Barone, E.; Perluigi, M.; Butterfield, D.A. The Triangle of Death in Alzheimer's Disease Brain: The Aberrant Cross-Talk Among Energy Metabolism, Mammalian Target of Rapamycin Signaling, and Protein Homeostasis Revealed by Redox Proteomics. Antioxid. Redox Signal. 2017, 26, 364-387. [CrossRef] [PubMed]

197. Castegna, A.; Aksenov, M.; Aksenova, M.; Thongboonkerd, V.; Klein, J.B.; Pierce, W.M.; Booze, R.; Markesbery, W.R.; Butterfield, D.A. Proteomic identification of oxidatively modified proteins in Alzheimer's disease brain. Part I: Creatine kinase BB, glutamine synthase, and ubiquitin carboxy-terminal hydrolase L-1. Free Radic. Biol. Med. 2002, 33, 562-571. [CrossRef]

198. Di Domenico, F.; Head, E.; Butterfield, D.A.; Perluigi, M. Oxidative Stress and Proteostasis Network: Culprit and Casualty of Alzheimer's-Like Neurodegeneration. Adv. Geriatr. 2014, 2014, 527518. [CrossRef]

199. Zheng, L.; Kagedal, K.; Dehvari, N.; Benedikz, E.; Cowburn, R.; Marcusson, J.; Terman, A. Oxidative stress induces macroautophagy of amyloid beta-protein and ensuing apoptosis. Free Radic. Biol. Med. 2009, 46, 422-429. [CrossRef]

200. Liang, J.H.; Jia, J.P. Dysfunctional autophagy in Alzheimer's disease: Pathogenic roles and therapeutic implications. Neurosci. Bull. 2014, 30, 308-316. [CrossRef]

201. Piras, A.; Collin, L.; Gruninger, F.; Graff, C.; Ronnback, A. Autophagic and lysosomal defects in human tauopathies: Analysis of post-mortem brain from patients with familial Alzheimer disease, corticobasal degeneration and progressive supranuclear palsy. Acta Neuropathol. Commun. 2016, 4, 22. [CrossRef]

202. Butzlaff, M.; Hannan, S.B.; Karsten, P.; Lenz, S.; Ng, J.; Vossfeldt, H.; Prussing, K.; Pflanz, R.; Schulz, J.B.; Rasse, T.; et al. Impaired retrograde transport by the Dynein/Dynactin complex contributes to Tau-induced toxicity. Hum. Mol. Genet. 2015, 24, 3623-3637. [CrossRef] [PubMed]

203. Caccamo, A.; Magri, A.; Medina, D.X.; Wisely, E.V.; Lopez-Aranda, M.F.; Silva, A.J.; Oddo, S. mTOR regulates tau phosphorylation and degradation: Implications for Alzheimer's disease and other tauopathies. Aging Cell 2013, 12, 370-380. [CrossRef] [PubMed]

204. Vidal, R.L.; Matus, S.; Bargsted, L.; Hetz, C. Targeting autophagy in neurodegenerative diseases. Trends Pharmacol. Sci. 2014, 35, 583-591. [CrossRef] [PubMed]

205. Lang, A.E.; Lozano, A.M. Parkinson's disease. First of two parts. N. Engl. J. Med. 1998, 339, $1044-1053$. [CrossRef] [PubMed]

206. Wakabayashi, K.; Tanji, K.; Mori, F.; Takahashi, H. The Lewy body in Parkinson's disease: Molecules implicated in the formation and degradation of alpha-synuclein aggregates. Neuropathology 2007, 27, 494-506. [CrossRef]

207. Dick, F.D.; De Palma, G.; Ahmadi, A.; Scott, N.W.; Prescott, G.J.; Bennett, J.; Semple, S.; Dick, S.; Counsell, C.; Mozzoni, P.; et al. Environmental risk factors for Parkinson's disease and parkinsonism: The Geoparkinson study. Occup. Environ. Med. 2007, 64, 666-672. [CrossRef]

208. Kitada, T.; Asakawa, S.; Hattori, N.; Matsumine, H.; Yamamura, Y.; Minoshima, S.; Yokochi, M.; Mizuno, Y.; Shimizu, N. Mutations in the parkin gene cause autosomal recessive juvenile parkinsonism. Nature 1998, 392, 605-608. [CrossRef]

209. Dias, V.; Junn, E.; Mouradian, M.M. The role of oxidative stress in Parkinson's disease. J. Parkinsons Dis. 2013, 3, 461-491. [CrossRef]

210. Hwang, O. Role of oxidative stress in Parkinson's disease. Exp. Neurobiol. 2013, 22, 11-17. [CrossRef]

211. Yoritaka, A.; Hattori, N.; Uchida, K.; Tanaka, M.; Stadtman, E.R.; Mizuno, Y. Immunohistochemical detection of 4-hydroxynonenal protein adducts in Parkinson disease. Proc. Natl. Acad. Sci. USA 1996, 93, 2696-2701. [CrossRef] 
212. Floor, E.; Wetzel, M.G. Increased protein oxidation in human substantia nigra pars compacta in comparison with basal ganglia and prefrontal cortex measured with an improved dinitrophenylhydrazine assay. J. Neurochem. 1998, 70, 268-275. [CrossRef] [PubMed]

213. Zhang, J.; Perry, G.; Smith, M.A.; Robertson, D.; Olson, S.J.; Graham, D.G.; Montine, T.J. Parkinson's disease is associated with oxidative damage to cytoplasmic DNA and RNA in substantia nigra neurons. Am. J. Pathol. 1999, 154, 1423-1429. [CrossRef]

214. Sian, J.; Dexter, D.T.; Lees, A.J.; Daniel, S.; Agid, Y.; Javoy-Agid, F.; Jenner, P.; Marsden, C.D. Alterations in glutathione levels in Parkinson's disease and other neurodegenerative disorders affecting basal ganglia. Ann. Neurol. 1994, 36, 348-355. [CrossRef] [PubMed]

215. Chinta, S.J.; Kumar, M.J.; Hsu, M.; Rajagopalan, S.; Kaur, D.; Rane, A.; Nicholls, D.G.; Choi, J.; Andersen, J.K. Inducible alterations of glutathione levels in adult dopaminergic midbrain neurons result in nigrostriatal degeneration. J. Neurosci. 2007, 27, 13997-14006. [CrossRef]

216. Sian-Hulsmann, J.; Mandel, S.; Youdim, M.B.; Riederer, P. The relevance of iron in the pathogenesis of Parkinson's disease. J. Neurochem. 2011, 118, 939-957. [CrossRef]

217. Esteves, A.R.; Arduino, D.M.; Silva, D.F.; Oliveira, C.R.; Cardoso, S.M. Mitochondrial Dysfunction: The Road to Alpha-Synuclein Oligomerization in PD. Parkinsons Dis. 2011, 2011, 693761. [CrossRef]

218. Burre, J. The Synaptic Function of alpha-Synuclein. J. Parkinsons Dis. 2015, 5, 699-713. [CrossRef]

219. Webb, J.L.; Ravikumar, B.; Atkins, J.; Skepper, J.N.; Rubinsztein, D.C. Alpha-Synuclein is degraded by both autophagy and the proteasome. J. Biol. Chem. 2003, 278, 25009-25013. [CrossRef]

220. Vogiatzi, T.; Xilouri, M.; Vekrellis, K.; Stefanis, L. Wild type alpha-synuclein is degraded by chaperone-mediated autophagy and macroautophagy in neuronal cells. J. Biol. Chem. 2008, 283, 23542-23556. [CrossRef]

221. Cook, C.; Stetler, C.; Petrucelli, L. Disruption of protein quality control in Parkinson's disease. Cold Spring Harb. Perspect. Med. 2012, 2, a009423. [CrossRef]

222. McNaught, K.S.; Olanow, C.W.; Halliwell, B.; Isacson, O.; Jenner, P. Failure of the ubiquitin-proteasome system in Parkinson's disease. Nat. Rev. Neurosci. 2001, 2, 589-594. [CrossRef] [PubMed]

223. Zhang, N.Y.; Tang, Z.; Liu, C.W. alpha-Synuclein protofibrils inhibit $26 \mathrm{~S}$ proteasome-mediated protein degradation: Understanding the cytotoxicity of protein protofibrils in neurodegenerative disease pathogenesis. J. Biol. Chem. 2008, 283, 20288-20298. [CrossRef] [PubMed]

224. Alvarez-Erviti, L.; Rodriguez-Oroz, M.C.; Cooper, J.M.; Caballero, C.; Ferrer, I.; Obeso, J.A.; Schapira, A.H. Chaperone-mediated autophagy markers in Parkinson disease brains. Arch. Neurol. 2010, 67, 1464-1472. [CrossRef]

225. Martinez-Vicente, M.; Talloczy, Z.; Kaushik, S.; Massey, A.C.; Mazzulli, J.; Mosharov, E.V.; Hodara, R.; Fredenburg, R.; Wu, D.C.; Follenzi, A.; et al. Dopamine-modified alpha-synuclein blocks chaperone-mediated autophagy. J. Clin. Investig. 2008, 118, 777-788. [CrossRef] [PubMed]

226. Kabuta, T.; Furuta, A.; Aoki, S.; Furuta, K.; Wada, K. Aberrant interaction between Parkinson disease-associated mutant UCH-L1 and the lysosomal receptor for chaperone-mediated autophagy. J. Biol. Chem. 2008, 283, 23731-23738. [CrossRef]

227. Orenstein, S.J.; Kuo, S.H.; Tasset, I.; Arias, E.; Koga, H.; Fernandez-Carasa, I.; Cortes, E.; Honig, L.S.; Dauer, W.; Consiglio, A.; et al. Interplay of LRRK2 with chaperone-mediated autophagy. Nat. Neurosci. 2013, 16, 394-406. [CrossRef]

228. Winslow, A.R.; Chen, C.W.; Corrochano, S.; Acevedo-Arozena, A.; Gordon, D.E.; Peden, A.A.; Lichtenberg, M.; Menzies, F.M.; Ravikumar, B.; Imarisio, S.; et al. alpha-Synuclein impairs macroautophagy: Implications for Parkinson's disease. J. Cell Biol. 2010, 190, 1023-1037. [CrossRef]

229. Kane, L.A.; Lazarou, M.; Fogel, A.I.; Li, Y.; Yamano, K.; Sarraf, S.A.; Banerjee, S.; Youle, R.J. PINK1 phosphorylates ubiquitin to activate Parkin E3 ubiquitin ligase activity. J. Cell Biol. 2014, 205, 143-153. [CrossRef]

230. Koyano, F.; Okatsu, K.; Kosako, H.; Tamura, Y.; Go, E.; Kimura, M.; Kimura, Y.; Tsuchiya, H.; Yoshihara, H.; Hirokawa, T.; et al. Ubiquitin is phosphorylated by PINK1 to activate parkin. Nature 2014, 510, 162-166. [CrossRef]

231. Pickrell, A.M.; Youle, R.J. The roles of PINK1, parkin, and mitochondrial fidelity in Parkinson's disease. Neuron 2015, 85, 257-273. [CrossRef] 
232. Lee, J.Y.; Nagano, Y.; Taylor, J.P.; Lim, K.L.; Yao, T.P. Disease-causing mutations in parkin impair mitochondrial ubiquitination, aggregation, and HDAC6-dependent mitophagy. J. Cell Biol. 2010, 189, 671-679. [CrossRef] [PubMed]

233. Liu, W.; Vives-Bauza, C.; Acin-Perez, R.; Yamamoto, A.; Tan, Y.; Li, Y.; Magrane, J.; Stavarache, M.A.; Shaffer, S.; Chang, S.; et al. PINK1 defect causes mitochondrial dysfunction, proteasomal deficit and alpha-synuclein aggregation in cell culture models of Parkinson's disease. PLoS ONE 2009, 4, e4597. [CrossRef]

234. Tansey, M.G.; Goldberg, M.S. Neuroinflammation in Parkinson's disease: Its role in neuronal death and implications for therapeutic intervention. Neurobiol. Dis. 2010, 37, 510-518. [CrossRef] [PubMed]

235. Lee, H.J.; Suk, J.E.; Bae, E.J.; Lee, S.J. Clearance and deposition of extracellular alpha-synuclein aggregates in microglia. Biochem. Biophys. Res. Commun. 2008, 372, 423-428. [CrossRef]

236. Whitton, P.S. Inflammation as a causative factor in the aetiology of Parkinson's disease. Br. J. Pharmacol. 2007, 150, 963-976. [CrossRef]

237. Knott, C.; Stern, G.; Wilkin, G.P. Inflammatory regulators in Parkinson's disease: INOS, lipocortin-1, and cyclooxygenases-1 and -2. Mol. Cell Neurosci. 2000, 16, 724-739. [CrossRef]

238. Mogi, M.; Harada, M.; Riederer, P.; Narabayashi, H.; Fujita, K.; Nagatsu, T. Tumor necrosis factor-alpha (TNF-alpha) increases both in the brain and in the cerebrospinal fluid from parkinsonian patients. Neurosci. Lett. 1994, 165, 208-210. [CrossRef]

239. Mogi, M.; Harada, M.; Narabayashi, H.; Inagaki, H.; Minami, M.; Nagatsu, T. Interleukin (IL)-1 beta, IL-2, IL-4, IL-6 and transforming growth factor-alpha levels are elevated in ventricular cerebrospinal fluid in juvenile parkinsonism and Parkinson's disease. Neurosci. Lett. 1996, 211, 13-16. [CrossRef]

240. Blokhuis, A.M.; Groen, E.J.; Koppers, M.; van den Berg, L.H.; Pasterkamp, R.J. Protein aggregation in amyotrophic lateral sclerosis. Acta Neuropathol. 2013, 125, 777-794. [CrossRef]

241. Vargas, M.R.; Johnson, J.A. Astrogliosis in amyotrophic lateral sclerosis: Role and therapeutic potential of astrocytes. Neurotherapeutics 2010, 7, 471-481. [CrossRef]

242. Rosen, D.R.; Siddique, T.; Patterson, D.; Figlewicz, D.A.; Sapp, P.; Hentati, A.; Donaldson, D.; Goto, J.; O'Regan, J.P.; Deng, H.X.; et al. Mutations in $\mathrm{Cu} / \mathrm{Zn}$ superoxide dismutase gene are associated with familial amyotrophic lateral sclerosis. Nature 1993, 362, 59-62. [CrossRef]

243. Contestabile, A. Amyotrophic lateral sclerosis: From research to therapeutic attempts and therapeutic perspectives. Curr. Med. Chem. 2011, 18, 5655-5665. [CrossRef] [PubMed]

244. Shaw, P.J.; Ince, P.G.; Falkous, G.; Mantle, D. Oxidative damage to protein in sporadic motor neuron disease spinal cord. Ann. Neurol. 1995, 38, 691-695. [CrossRef] [PubMed]

245. Beal, M.F.; Ferrante, R.J.; Browne, S.E.; Matthews, R.T.; Kowall, N.W.; Brown, R.H., Jr. Increased 3-nitrotyrosine in both sporadic and familial amyotrophic lateral sclerosis. Ann. Neurol. 1997, 42, 644-654. [CrossRef] [PubMed]

246. Abe, K.; Pan, L.H.; Watanabe, M.; Konno, H.; Kato, T.; Itoyama, Y. Upregulation of protein-tyrosine nitration in the anterior horn cells of amyotrophic lateral sclerosis. Neurol. Res. 1997, 19, 124-128. [CrossRef] [PubMed]

247. Tohgi, H.; Abe, T.; Yamazaki, K.; Murata, T.; Ishizaki, E.; Isobe, C. Remarkable increase in cerebrospinal fluid 3-nitrotyrosine in patients with sporadic amyotrophic lateral sclerosis. Ann. Neurol. 1999, 46, 129-131. [CrossRef]

248. Ferrante, R.J.; Browne, S.E.; Shinobu, L.A.; Bowling, A.C.; Baik, M.J.; MacGarvey, U.; Kowall, N.W.; Brown, R.H., Jr.; Beal, M.F. Evidence of increased oxidative damage in both sporadic and familial amyotrophic lateral sclerosis. J. Neurochem. 1997, 69, 2064-2074. [CrossRef]

249. Smith, R.G.; Henry, Y.K.; Mattson, M.P.; Appel, S.H. Presence of 4-hydroxynonenal in cerebrospinal fluid of patients with sporadic amyotrophic lateral sclerosis. Ann. Neurol. 1998, 44, 696-699. [CrossRef]

250. Carri, M.T.; Ferri, A.; Cozzolino, M.; Calabrese, L.; Rotilio, G. Neurodegeneration in amyotrophic lateral sclerosis: The role of oxidative stress and altered homeostasis of metals. Brain Res. Bull. 2003, 61, 365-374. [CrossRef]

251. Rothstein, J.D.; Tsai, G.; Kuncl, R.W.; Clawson, L.; Cornblath, D.R.; Drachman, D.B.; Pestronk, A.; Stauch, B.L.; Coyle, J.T. Abnormal excitatory amino acid metabolism in amyotrophic lateral sclerosis. Ann. Neurol. 1990, 28, 18-25. [CrossRef]

252. Siklos, L.; Engelhardt, J.; Harati, Y.; Smith, R.G.; Joo, F.; Appel, S.H. Ultrastructural evidence for altered calcium in motor nerve terminals in amyotropic lateral sclerosis. Ann. Neurol. 1996, 39, 203-216. [CrossRef] [PubMed] 
253. Rothstein, J.D.; Van Kammen, M.; Levey, A.I.; Martin, L.J.; Kuncl, R.W. Selective loss of glial glutamate transporter GLT-1 in amyotrophic lateral sclerosis. Ann. Neurol. 1995, 38, 73-84. [CrossRef] [PubMed]

254. Rothstein, J.D.; Martin, L.J.; Kuncl, R.W. Decreased glutamate transport by the brain and spinal cord in amyotrophic lateral sclerosis. N. Engl. J. Med. 1992, 326, 1464-1468. [CrossRef] [PubMed]

255. Weiss, J.H. Ca permeable AMPA channels in diseases of the nervous system. Front. Mol. Neurosci. $2011,4,42$. [CrossRef] [PubMed]

256. Van Den Bosch, L.; Van Damme, P.; Bogaert, E.; Robberecht, W. The role of excitotoxicity in the pathogenesis of amyotrophic lateral sclerosis. Biochim. Biophys. Acta 2006, 1762, 1068-1082. [CrossRef]

257. Dykens, J.A. Isolated cerebral and cerebellar mitochondria produce free radicals when exposed to elevated CA2+ and Na+: Implications for neurodegeneration. J. Neurochem. 1994, 63, 584-591. [CrossRef]

258. Trotti, D.; Danbolt, N.C.; Volterra, A. Glutamate transporters are oxidant-vulnerable: A molecular link between oxidative and excitotoxic neurodegeneration? Trends Pharmacol. Sci. 1998, 19, 328-334. [CrossRef]

259. Pedersen, W.A.; Fu, W.; Keller, J.N.; Markesbery, W.R.; Appel, S.; Smith, R.G.; Kasarskis, E.; Mattson, M.P. Protein modification by the lipid peroxidation product 4-hydroxynonenal in the spinal cords of amyotrophic lateral sclerosis patients. Ann. Neurol. 1998, 44, 819-824. [CrossRef]

260. Neumann, M.; Sampathu, D.M.; Kwong, L.K.; Truax, A.C.; Micsenyi, M.C.; Chou, T.T.; Bruce, J.; Schuck, T.; Grossman, M.; Clark, C.M.; et al. Ubiquitinated TDP-43 in frontotemporal lobar degeneration and amyotrophic lateral sclerosis. Science 2006, 314, 130-133. [CrossRef]

261. Arai, T.; Hasegawa, M.; Akiyama, H.; Ikeda, K.; Nonaka, T.; Mori, H.; Mann, D.; Tsuchiya, K.; Yoshida, M.; Hashizume, Y.; et al. TDP-43 is a component of ubiquitin-positive tau-negative inclusions in frontotemporal lobar degeneration and amyotrophic lateral sclerosis. Biochem. Biophys. Res. Commun. 2006, 351, 602-611. [CrossRef]

262. Tan, C.F.; Eguchi, H.; Tagawa, A.; Onodera, O.; Iwasaki, T.; Tsujino, A.; Nishizawa, M.; Kakita, A.; Takahashi, H. TDP-43 immunoreactivity in neuronal inclusions in familial amyotrophic lateral sclerosis with or without SOD1 gene mutation. Acta Neuropathol. 2007, 113, 535-542. [CrossRef] [PubMed]

263. Barmada, S.J.; Skibinski, G.; Korb, E.; Rao, E.J.; Wu, J.Y.; Finkbeiner, S. Cytoplasmic mislocalization of TDP-43 is toxic to neurons and enhanced by a mutation associated with familial amyotrophic lateral sclerosis. J. Neurosci. 2010, 30, 639-649. [CrossRef] [PubMed]

264. Bruijn, L.I.; Houseweart, M.K.; Kato, S.; Anderson, K.L.; Anderson, S.D.; Ohama, E.; Reaume, A.G.; Scott, R.W.; Cleveland, D.W. Aggregation and motor neuron toxicity of an ALS-linked SOD1 mutant independent from wild-type SOD1. Science 1998, 281, 1851-1854. [CrossRef] [PubMed]

265. Kwiatkowski, T.J., Jr.; Bosco, D.A.; Leclerc, A.L.; Tamrazian, E.; Vanderburg, C.R.; Russ, C.; Davis, A.; Gilchrist, J.; Kasarskis, E.J.; Munsat, T.; et al. Mutations in the FUS/TLS gene on chromosome 16 cause familial amyotrophic lateral sclerosis. Science 2009, 323, 1205-1208. [CrossRef]

266. Polymenidou, M.; Cleveland, D.W. The seeds of neurodegeneration: Prion-like spreading in ALS. Cell 2011, 147, 498-508. [CrossRef]

267. Kabashi, E.; Agar, J.N.; Strong, M.J.; Durham, H.D. Impaired proteasome function in sporadic amyotrophic lateral sclerosis. Amyotroph. Lateral. Scler. 2012, 13, 367-371. [CrossRef]

268. Bendotti, C.; Marino, M.; Cheroni, C.; Fontana, E.; Crippa, V.; Poletti, A.; De Biasi, S. Dysfunction of constitutive and inducible ubiquitin-proteasome system in amyotrophic lateral sclerosis: Implication for protein aggregation and immune response. Prog. Neurobiol. 2012, 97, 101-126. [CrossRef]

269. van Eersel, J.; Ke, Y.D.; Gladbach, A.; Bi, M.; Gotz, J.; Kril, J.J.; Ittner, L.M. Cytoplasmic accumulation and aggregation of TDP-43 upon proteasome inhibition in cultured neurons. PLoS ONE 2011, 6, e22850. [CrossRef]

270. Fecto, F.; Siddique, T. UBQLN2/P62 cellular recycling pathways in amyotrophic lateral sclerosis and frontotemporal dementia. Muscle Nerve 2012, 45, 157-162. [CrossRef]

271. Fecto, F.; Yan, J.; Vemula, S.P.; Liu, E.; Yang, Y.; Chen, W.; Zheng, J.G.; Shi, Y.; Siddique, N.; Arrat, H.; et al. SQSTM1 mutations in familial and sporadic amyotrophic lateral sclerosis. Arch. Neurol. 2011, 68, 1440-1446. [CrossRef]

272. Chen, S.; Zhang, X.; Song, L.; Le, W. Autophagy dysregulation in amyotrophic lateral sclerosis. Brain Pathol. 2012, 22, 110-116. [CrossRef] [PubMed] 
273. Fiala, M.; Chattopadhay, M.; La Cava, A.; Tse, E.; Liu, G.; Lourenco, E.; Eskin, A.; Liu, P.T.; Magpantay, L.; Tse, S.; et al. IL-17A is increased in the serum and in spinal cord CD8 and mast cells of ALS patients. J. Neuroinflamm. 2010, 7, 76. [CrossRef] [PubMed]

274. Kuhle, J.; Lindberg, R.L.; Regeniter, A.; Mehling, M.; Steck, A.J.; Kappos, L.; Czaplinski, A. Increased levels of inflammatory chemokines in amyotrophic lateral sclerosis. Eur. J. Neurol. 2009, 16, 771-774. [CrossRef]

275. Casula, M.; Iyer, A.M.; Spliet, W.G.; Anink, J.J.; Steentjes, K.; Sta, M.; Troost, D.; Aronica, E. Toll-like receptor signaling in amyotrophic lateral sclerosis spinal cord tissue. Neuroscience 2011, 179, 233-243. [CrossRef]

276. Berghofer, P.; Peterson, R.G.; Schneider, K.; Fehmann, H.C.; Goke, B. Incretin hormone expression in the gut of diabetic mice and rats. Metabolism 1997, 46, 261-267. [CrossRef]

277. Sperlagh, B.; Vizi, E.S.; Wirkner, K.; Illes, P. P2X7 receptors in the nervous system. Prog. Neurobiol. 2006, 78, 327-346. [CrossRef] [PubMed]

278. Volonte, C.; Apolloni, S.; Parisi, C.; Amadio, S. Purinergic contribution to amyotrophic lateral sclerosis. Neuropharmacology 2016, 104, 180-193. [CrossRef]

279. Komatsu, M.; Kurokawa, H.; Waguri, S.; Taguchi, K.; Kobayashi, A.; Ichimura, Y.; Sou, Y.S.; Ueno, I.; Sakamoto, A.; Tong, K.I.; et al. The selective autophagy substrate p62 activates the stress responsive transcription factor Nrf2 through inactivation of Keap1. Nat. Cell Biol. 2010, 12, 213-223. [CrossRef]

280. Suzuki, T.; Motohashi, H.; Yamamoto, M. Toward clinical application of the Keap1-Nrf2 pathway. Trends Pharmacol. Sci. 2013, 34, 340-346. [CrossRef]

281. Dinkova-Kostova, A.T.; Abramov, A.Y. The emerging role of Nrf2 in mitochondrial function. Free Radic. Biol. Med. 2015, 88, 179-188. [CrossRef]

282. Michalska, P.; Buendia, I.; Duarte, P.; FernandezMendivil, C.; Negredo, P.; Cuadrado, A.; Lopez, M.G.; Leon, R. Melatonin-sulforaphane hybrid ITH12674 attenuates glial response in vivo by blocking LPS binding to MD2 and receptor oligomerization. Pharmacol. Res. 2020, 152, 104597. [CrossRef] [PubMed]

283. Kim, J.E.; You, D.J.; Lee, C.; Ahn, C.; Seong, J.Y.; Hwang, J.I. Suppression of NF-kappaB signaling by KEAP1 regulation of IKKbeta activity through autophagic degradation and inhibition of phosphorylation. Cell Signal. 2010, 22, 1645-1654. [CrossRef] [PubMed]

284. Liu, G.H.; Qu, J.; Shen, X. NF-kappaB/p65 antagonizes Nrf2-ARE pathway by depriving CBP from Nrf2 and facilitating recruitment of HDAC3 to MafK. Biochim. Biophys. Acta 2008, 1783, 713-727. [CrossRef] [PubMed]

285. Yu, M.; Li, H.; Liu, Q.; Liu, F.; Tang, L.; Li, C.; Yuan, Y.; Zhan, Y.; Xu, W.; Li, W.; et al. Nuclear factor p65 interacts with Keap1 to repress the Nrf2-ARE pathway. Cell Signal. 2011, 23, 883-892. [CrossRef]

286. Jain, A.; Lamark, T.; Sjottem, E.; Larsen, K.B.; Awuh, J.A.; Overvatn, A.; McMahon, M.; Hayes, J.D.; Johansen, T. p62/SQSTM1 is a target gene for transcription factor NRF2 and creates a positive feedback loop by inducing antioxidant response element-driven gene transcription. J. Biol. Chem. 2010, 285, 22576-22591. [CrossRef]

287. Jo, C.; Gundemir, S.; Pritchard, S.; Jin, Y.N.; Rahman, I.; Johnson, G.V. Nrf2 reduces levels of phosphorylated tau protein by inducing autophagy adaptor protein NDP52. Nat. Commun. 2014, 5, 3496. [CrossRef]

288. Pajares, M.; Jimenez-Moreno, N.; Garcia-Yague, A.J.; Escoll, M.; de Ceballos, M.L.; Van Leuven, F.; Rabano, A.; Yamamoto, M.; Rojo, A.I.; Cuadrado, A. Transcription factor NFE2L2/NRF2 is a regulator of macroautophagy genes. Autophagy 2016, 12, 1902-1916. [CrossRef]

289. Pajares, M.; Rojo, A.I.; Arias, E.; Diaz-Carretero, A.; Cuervo, A.M.; Cuadrado, A. Transcription factor NFE2L2/NRF2 modulates chaperone-mediated autophagy through the regulation of LAMP2A. Autophagy 2018, 14, 1310-1322. [CrossRef]

290. Brandes, M.S.; Gray, N.E. NRF2 as a Therapeutic Target in Neurodegenerative Diseases. ASN Neuro 2020, 12, 1759091419899782. [CrossRef]

291. Buendia, I.; Michalska, P.; Navarro, E.; Gameiro, I.; Egea, J.; Leon, R. Nrf2-ARE pathway: An emerging target against oxidative stress and neuroinflammation in neurodegenerative diseases. Pharmacol. Ther. 2016, 157, 84-104. [CrossRef]

292. Dinkova-Kostova, A.T.; Kostov, R.V.; Kazantsev, A.G. The role of Nrf2 signaling in counteracting neurodegenerative diseases. FEBS J. 2018, 285, 3576-3590. [CrossRef] [PubMed]

293. Cores, A.; Piquero, M.; Villacampa, M.; Leon, R.; Menendez, J.C. NRF2 Regulation Processes as a Source of Potential Drug Targets against Neurodegenerative Diseases. Biomolecules 2020, 10. [CrossRef] [PubMed]

294. Cuadrado, A.; Manda, G.; Hassan, A.; Alcaraz, M.J.; Barbas, C.; Daiber, A.; Ghezzi, P.; Leon, R.; Lopez, M.G.; Oliva, B.; et al. Transcription Factor NRF2 as a Therapeutic Target for Chronic Diseases: A Systems Medicine Approach. Pharmacol. Rev. 2018, 70, 348-383. [CrossRef] [PubMed] 
295. Xu, Z.; Zhang, F.; Sun, F.; Gu, K.; Dong, S.; He, D. Dimethyl fumarate for multiple sclerosis. Cochrane Database Syst. Rev. 2015. [CrossRef] [PubMed]

296. Paraiso, H.C.; Kuo, P.C.; Curfman, E.T.; Moon, H.J.; Sweazey, R.D.; Yen, J.H.; Chang, F.L.; Yu, I.C. Dimethyl fumarate attenuates reactive microglia and long-term memory deficits following systemic immune challenge. J. Neuroinflamm. 2018, 15, 100. [CrossRef] [PubMed]

297. Rojo, A.I.; Pajares, M.; Garcia-Yague, A.J.; Buendia, I.; Van Leuven, F.; Yamamoto, M.; Lopez, M.G.; Cuadrado, A. Deficiency in the transcription factor NRF2 worsens inflammatory parameters in a mouse model with combined tauopathy and amyloidopathy. Redox Biol. 2018, 18, 173-180. [CrossRef]

298. Lastres-Becker, I.; Garcia-Yague, A.J.; Scannevin, R.H.; Casarejos, M.J.; Kugler, S.; Rabano, A.; Cuadrado, A. Repurposing the NRF2 Activator Dimethyl Fumarate as Therapy Against Synucleinopathy in Parkinson's Disease. Antioxid. Redox Signal. 2016, 25, 61-77. [CrossRef]

299. Wilms, H.; Sievers, J.; Rickert, U.; Rostami-Yazdi, M.; Mrowietz, U.; Lucius, R. Dimethylfumarate inhibits microglial and astrocytic inflammation by suppressing the synthesis of nitric oxide, IL-1beta, TNF-alpha and IL-6 in an in-vitro model of brain inflammation. J. Neuroinflamm. 2010, 7, 30. [CrossRef]

300. Beers, D.R.; Henkel, J.S.; Zhao, W.; Wang, J.; Huang, A.; Wen, S.; Liao, B.; Appel, S.H. Endogenous regulatory $\mathrm{T}$ lymphocytes ameliorate amyotrophic lateral sclerosis in mice and correlate with disease progression in patients with amyotrophic lateral sclerosis. Brain 2011, 134, 1293-1314. [CrossRef]

301. Thonhoff, J.R.; Beers, D.R.; Zhao, W.; Pleitez, M.; Simpson, E.P.; Berry, J.D.; Cudkowicz, M.E.; Appel, S.H. Expanded autologous regulatory T-lymphocyte infusions in ALS: A phase I, first-in-human study. Neurol. Neuroimmunol. Neuroinflamm. 2018, 5, e465. [CrossRef]

302. Havrdova, E.; Hutchinson, M.; Kurukulasuriya, N.C.; Raghupathi, K.; Sweetser, M.T.; Dawson, K.T.; Gold, R. Oral BG-12 (dimethyl fumarate) for relapsing-remitting multiple sclerosis: A review of DEFINE and CONFIRM. Evaluation of: Gold R, Kappos L, Arnold D, et al. Placebo-controlled phase 3 study of oral BG-12 for relapsing multiple sclerosis. N Engl J Med 2012;367:1098-107; and Fox RJ, Miller DH, Phillips JT, et al. Placebo-controlled phase 3 study of oral BG-12 or glatiramer in multiple sclerosis. N Engl J Med 2012;367:1087-97. Expert Opin. Pharmacother. 2013, 14, 2145-2156. [CrossRef] [PubMed]

303. Gross, C.C.; Schulte-Mecklenbeck, A.; Klinsing, S.; Posevitz-Fejfar, A.; Wiendl, H.; Klotz, L. Dimethyl fumarate treatment alters circulating $\mathrm{T}$ helper cell subsets in multiple sclerosis. Neurol. Neuroimmunol. Neuroinflamm. 2016, 3, e183. [CrossRef] [PubMed]

304. Vucic, S.; Ryder, J.; Mekhael, L.; Rd, H.; Mathers, S.; Needham, M.; Dw, S.; Mc, K.; TEALS study group. Phase 2 randomized placebo controlled double blind study to assess the efficacy and safety of tecfidera in patients with amyotrophic lateral sclerosis (TEALS Study): Study protocol clinical trial (SPIRIT Compliant). Medicine 2020, 99, e18904. [CrossRef] [PubMed]

305. Shuaib, A.; Lees, K.R.; Lyden, P.; Grotta, J.; Davalos, A.; Davis, S.M.; Diener, H.C.; Ashwood, T.; Wasiewski, W.W.; Emeribe, U.; et al. NXY-059 for the treatment of acute ischemic stroke. N. Engl. J. Med. 2007, 357, 562-571. [CrossRef] [PubMed]

306. The RANTTAS Investigators. A randomized trial of tirilazad mesylate in patients with acute stroke (RANTTAS). Stroke 1996, 27, 1453-1458. [CrossRef]

307. Yamaguchi, T.; Sano, K.; Takakura, K.; Saito, I.; Shinohara, Y.; Asano, T.; Yasuhara, H. Ebselen in acute ischemic stroke: A placebo-controlled, double-blind clinical trial. Ebselen Study Group. Stroke 1998, 29, 12-17. [CrossRef]

308. Toyoda, K.; Fujii, K.; Kamouchi, M.; Nakane, H.; Arihiro, S.; Okada, Y.; Ibayashi, S.; Iida, M. Free radical scavenger, edaravone, in stroke with internal carotid artery occlusion. J. Neurol. Sci. 2004, 221, 11-17. [CrossRef]

309. Halliwell, B. The antioxidant paradox. Lancet 2000, 355, 1179-1180. [CrossRef]

310. Steinhubl, S.R. Why have antioxidants failed in clinical trials? Am. J. Cardiol. 2008, 101, 14D-19D. [CrossRef]

311. Bast, A.; Haenen, G.R. Ten misconceptions about antioxidants. Trends Pharmacol. Sci. 2013, 34, 430-436. [CrossRef]

312. Muller, M.; Banning, A.; Brigelius-Flohe, R.; Kipp, A. Nrf2 target genes are induced under marginal selenium-deficiency. Genes Nutr. 2010, 5, 297-307. [CrossRef] 
(C) 2020 by the authors. Licensee MDPI, Basel, Switzerland. This article is an open access article distributed under the terms and conditions of the Creative Commons Attribution (CC BY) license (http://creativecommons.org/licenses/by/4.0/). 